\title{
Kilka uwag o medalach portretowych Zygmunta I Starego
}

DOI: https://doi.org/10.21697/an.7923

MATEUSZ GRZĘDA

INSTYTUT HISTORII SZTUKI U

ORCID: 0000-0002-7077-1922

Jednym z najciekawszych fenomenów towarzyszących przemianom portretu u progu epoki nowożytnej jest upowszechnienie się medali portretowych*. Z racji podobieństwa do monet medale są naturalnym obszarem zainteresowania numizmatyków i przez długi czas niezasłużenie zajmowały marginalne miejsce w głównym nurcie badań historii sztuki. Tymczasem w XV i XVI w. medale stanowiły jedną z najoryginalniejszych form reprezentacji, która dzięki dużej ilości informacji na temat przedstawionej osoby, skumulowanej w niewielkim trwałym, mobilnym i łatwym do powielenia przedmiocie, doskonale odpowiadała renesansowemu postulatowi sławy i nieśmiertelności'. Możliwości, jakie

Niniejszy artykuł jest rezultatem badań prowadzonyc w ramach projektu finansowanego przez Ministerstwo Nauki i Szkolnictwa Wyżzzego (NPRH nr 0467/NPRHS/ Polski i Wielkich Książąt Litewskich oraz członków ic rodzin", realizowanego w Instytucie Historii Sztuki U U w ramach grantu „Epoka jagiellonska i jej dziedzictwo kultury materialnej, dzieje piśmiennictwa XIV-XVI wiek" Polskiego Towarzystwa Historycznego. Za lekturę teks i krytyczne uwagi serdecznie dziękuję prof. Markow oferował ten gatunek artystyczny, zostały zauważone w dworskim kręgu Zygmunta I Starego, co zaowocowało kilkoma seriami lanych i bitych w różnych metalach medali przedstawiających polskiego króla, powstałych na przestrzeni drugiego i trzeciego dziesięciolecia XVI w.2 Celem ninneçegego artykulu jest rozwazenie prown tykulu jest rozważenie proweniencji artystycznej tych medali, okoliczności ich powstania i zastanowienie się nad rolą, jaką mogły pełnić w praktyce władzy Zygmunta W $1526 \mathrm{r}$. kanclerz wielki koronny Krzysztof Szydłowiecki zwrócił się w liście do księcia Albrechta Hohenzollerna z prośbą, aby wysłał do niego rzeźbiarza, o ktorym usłyszał od gdańskiego malarza

Michała, że „oddaje znakomicie wizerunki ludzkie w płytach brązowych, kamieniu idrzewie" ${ }^{\prime}$. Rzeźbiarzem tym był, wedle

Walcz
skiej. Zob. S.K. Scher, Introduction, w: The Currency of Fame. Portrk 1994, s. 13-2

Ostatnio na temat medali Zygmunta I nappetniej wypowiadał się Mieczysław Morka, zob. M. Morka Sztuka dworu Zygmunta I Starego. Treści polityczne ipropagandowe, Warszawa 2006, s. 313-327, tenze, the Times of zygmunt and Bu Poran ans et Historiae", vol. 39, 2008, nr 58, z. 58, s. . 65-87. J. Kieszkowski, Kanclerz Krzysztof Szydlowiech. zdziejów kultury i sztuki zygmuntowskich czasów, t.
1. Hans Schenk, zw. Scheusslich Zygmunta I, 1526r., Wrocław, Zakład Narodowy im. Ossolińskich. Fot. ZNiO

wszelkiego prawdopodobieństwa, nie Hans Schwarz, jak jeszcze do niedawna utrzymywała polska historiografia 4 , lecz Hans Schenck, zw. Scheusslich, artysta pochodzący z miasteczka Schneeberg

w Rudawach (Górna Saksonia), który wyspecjalizował się w medalierstwie

w Norymberdze w latach 20. XVI w., a w latach 1527-1528 był zatrudniony jako kunter fetter na dworze książęcym Albrechta

w Królewcus. Wiosnę i lato 1526 r. Zygmunt wraz z Szydłowieckim spędzili w Malborku i Gdańsku, odzie spotkali się z Albrechtem. Wszystko wskazuje na to, że towarzyszący wówczas księciu Schenck wykonał modele portretowe króla i kanclerza, które zostały wykorzystane do kilku wersji medali królewskich, odlanych w latach 1526-1527 w złocie, srebrze i brązie ${ }^{6}$. Jedna wersja z tej grupy, której najlepszy - zapewne autorstwa samego Schencka - egzemplarz przechowywany jest w Zakładzie im. Ossolińskich we Wrocławiu (il. 1), powstała bez wątpienia

Poznań 1912, s. 374; A. Cante, Der Bildhauer und Medailleur Hans Schenck, oder Scheußlich. Ein Künstler der Renaissance in Zeitten der Reformation, Bd. I, Berll 2007, s. 388 . Zob. Zalze M. Monka, Sztuka dworu..., dz in Erz. Porträtmedaillen der deutschen Renaissance, hrsg. von W. Cupperi, M. Hirsch, A. Kranz, U. Pfisterer, Berlin-München 2013, s. 270.

M. Gumowski, Hans Schwarzi i jego polskie medale, „Prace Komisji Historii Sztuki", t. 1, 1917, nr 1, s. 88-108 A. Więcek, Dzieje sztuki medalierskiej W Polsce, Krak 1972, s. 14-19; M. Morka, Sztuka dworu..., dz. cyt., C. Habich Diedeutschen Schoumïnzen des XVI Jahrhunderts, Bd. 2, München 1932, nr kat 2204-22 J.F. Seeger, Hans Schenck (genannt Scheußlich). Ein deutscher Bildhauer des 16. Jahrhunderts, Berlin 1932,

s. 84; A. Cante, dz. cyt., Bd. 1.

M. Morka, Sztuka dworu..., dz. cyt., s. 313; Polen. Goldmedaille nach Art des Hans Schwarz auf den polnischen Konig Sigismund I, w: Die grosse Kunstkam[katalog wystawy] hrsg. von S. Söll-Tauchert Base 2011, s. 172-174 nr kat. 8 (oprac. M. Matzke); Hans Schenck oder Scheußlich. König Sigismund I. von Polen 1527, w: Wettstreit in Erz..., dz. cyt., s. 274, nr kat. 188

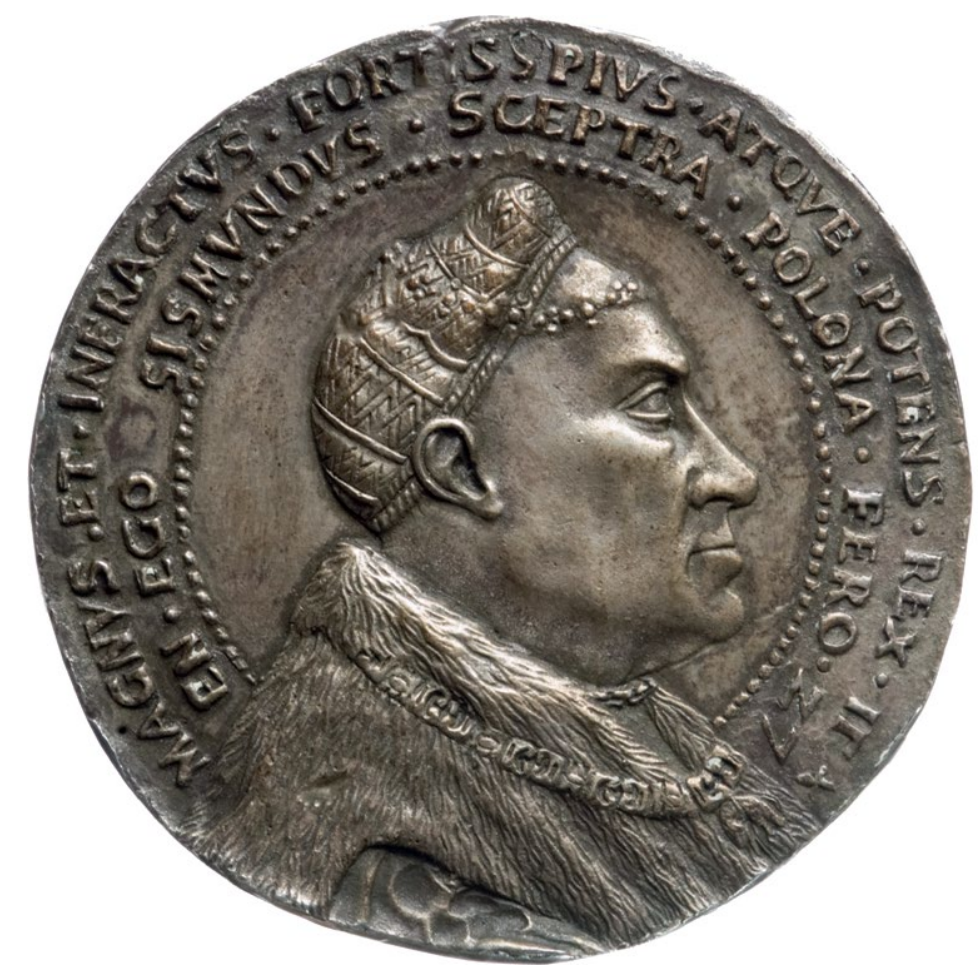

jako pendant dla medalu z wyobrażeniem Szydłowieckiego, który znany jest dziś tylko $z$ jednego oryginalnego odlewu zachowanego w Ermitażu w St. Petersburgu?. Obaj portretowani prezentują się w profilach, lecz zwróceni w przeciwnych kierunkach, w podobnych strojach: w szubach podbitych futrem i ozdobnych czepcach, opasanych górą narzuconymi łańcuchami z klejnotami. Na podstawie tego samego modelu powstać musiał także inny medal, przechowywany w Muzeum Historycznym w Bazylei, który został zadedykowany Erazmowi z Rotterdamu przez Seweryna

7 Polen. Goldmedaille nach Art des Hans Schwarz..., dz. cyt., s. 174; Hans Schenck oder Scheußlich..., dz. cyt., 1906, s. 57, nr kat. 59; tenże, Hans Schwarz.., dz. cyt., 5. 98-99, G. Habich, Die deutschen Schaumunzen... medal order. Katalog wystawy whasny, Moneta numizmatycznych Biblioteki Zakładu Narodowego in Ossolińskich-PAN, Wrocław-Warszawa-KrakówGdańsk 1971, s. 32, gablota V, nr 5; M. Morka, Sztuka dworu..., dz. cyt., s. 313-314; A. Cante, dz. cyt., Bd. 1,

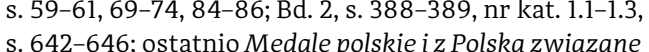
zokresu Pierwszej Rzeczypospolitei. Katalog zbiorów. Zamek Królewski w Warszawie - Muzeum. Fundacja zbiorów im. Ciechanowieckich, oprac. J. Zacher, G. Śnieżko, M. Zawadzki, wspơłpraca M. Męclewska, t. I, 

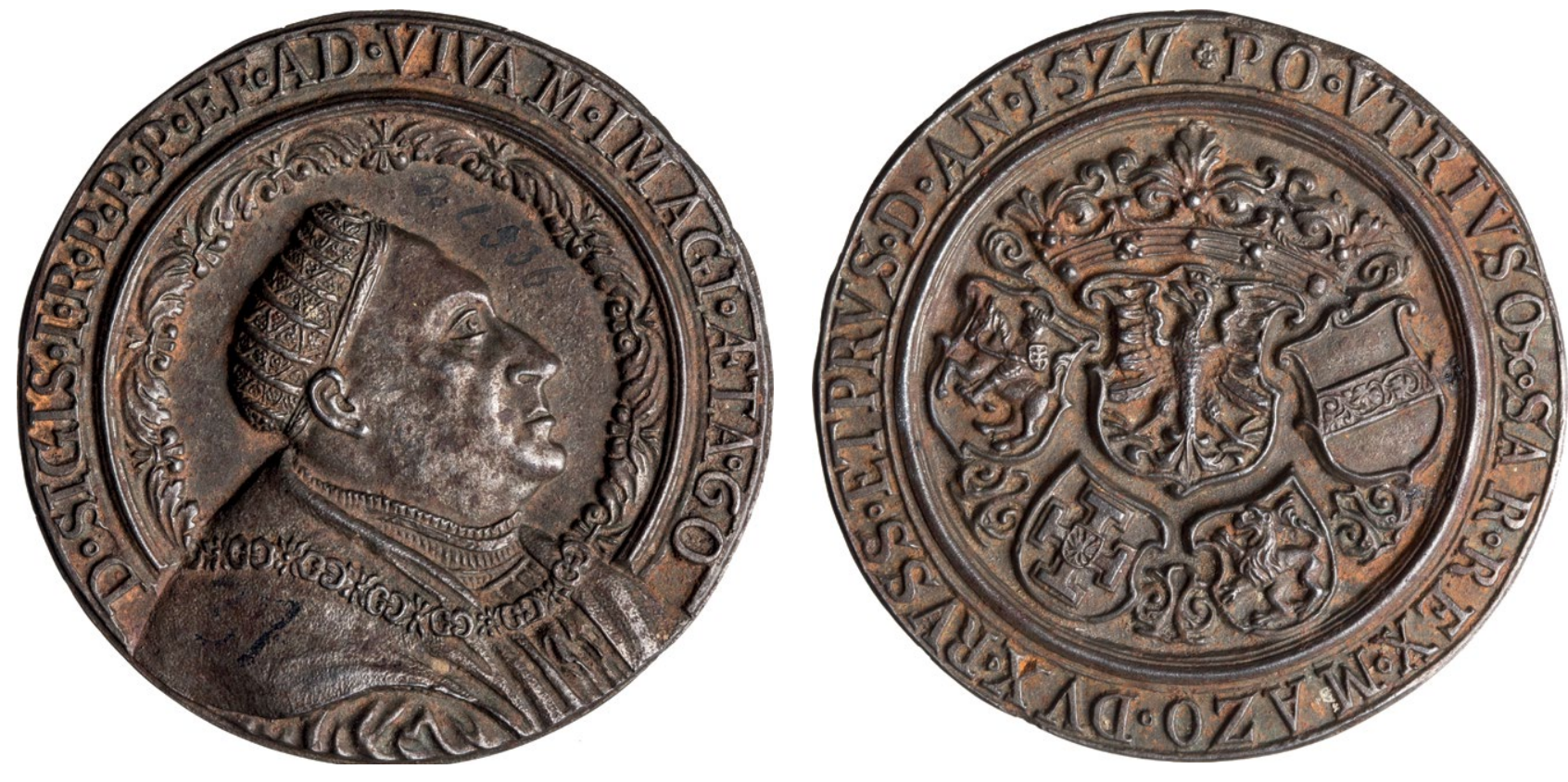

Wrocław, Zakład Narodowy im. Ossolińskich. Fot. ZNiO

Bonera i przesłany w dowód wdzięczności za roztoczenie opieki nad synem Janem, o co w 1531 r. zabiegał sam Zygmunt I ${ }^{8}$.

Pozostałe wersje prezentują nieco inne ujecie twarzy polskiego monarchy co pozwala sądzić, że nie wyszły spod dłuta Schencka, lecz powstały przy znajomości wykonanych przez niego modeli. Zalicza się do nich medal odlany w srebrze, przedstawiający króla bez diademu (Muzeum Narodowe w Warszawie)', oraz medal z datą 1527, znany z wysokiej jakości egzemplarzy w Zakładzie im. Ossolińskich (il. 2-3) i Kunsthistorisches Museum w Wiedniu (egzemplarz odlany w srebrze i pozlacany). Jest to zarazem medal najbardziej

F. Kopera, Dary z Polski dla Erazma z Rotterdam w Historycznem Muzeum Bazylejskiem, ,„Sprawozdania Komisyi do Badania Historyi Sztuki w Polsce", t. 6, 1900 s. 117-118; M. Gumowski, Medale jagiellonów..., dz. cyt,

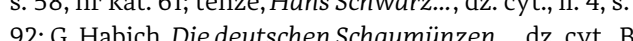
1, München 1929, s. 43, nr kat. 263, il. 54: M. Morka, Sztuka dworu..., dz. cyt., s. 314; Polen. Goldmedaille nach Art des Hans Schwarz.., dz. cyt., s. 172-174.

9 M. Gumowski, Medale Jagiellonów..., dz. cyt., s. 57-58, nr kat. 60; tenże, Hans Schwarz..., dz. cyt., il. 6, s. 100 uroczysty, w którym napis widniejący w otoku ujęty został profilowanymi listwami i który jako jedyny jest dwustronny. Na jego rewersie przedstawione zostały herby Królestwa Polskiego, Pogoń i herb

Habsburgów wraz z herbami nieistniejącego już Zakonu Krzyżackiego i Rusi ${ }^{10}$.

Inskrypcja w otoku awersu tego medalu odnosi się do wyobrażenia Zygmunta (w tłumaczeniu na język polski): „Boski Zygmunt król Polski ojciec ojczyzny z natury wizerunek wyobrażony w wieku lat 6o". Napis w otoku rewersu charakteryzuje natomias zakres terytorialny jego władzy powiększony dzięki inkorporacji Mazowsza holdzwaniu Prus (1525): Najpotęz zholdowaniu Proj obydwu Sarmacji kró, książę mazowieck

Wymienione medale nie były pierwszymi, które powstały w kręgu dworu

10 Zob. Z. Piech, Monety, pieczęcie i herby w systemie nr kat. 62; tenże, Hans Schwarzo..., dz. cyt.,.il. 8ai ib, s. 92; J.A. Szwagrzyk, dz. cyt., s. 32, gablota V, nr 6; M. Gumowski, Medale Jagiellonów M. Morka, Sztuka dworu..., dz. cyt., s. 318; Medale
Zygmunta I. W $1520 \mathrm{r}$. wykonany został medal z zawieszką, upamiętniający narodziny Zygmunta Augusta ${ }^{12}$. W odróżnieniu jedn od medali późniejszych nie był to medal portretowy. Wolno zatem podejrzewać, że prośba Szydłowieckiego zawarta w korespondencji z Albrechtem Hohenzollernem wynikała z chęci skorzystania z usług profesjonalnego artysty wyspecjalizowanego w tworzeniu małoformatowych przedstawień portretowych.

Jako samodzielny gatunek artystyczny medal wykształcił się na początku XV w. i szybko rozpowszechnił się we Wloszech, gdzie chętnie posługiwali się nim tamtejsi władcy, kondotierzy i przywódcy miast. W Europie północnej przez dłuższy czas medae nie wzbudzały większego zainteresowania - nawet jeżeli były znane, chociażby przez kontakty dyplomatyczne, handlowe i polityczne z ośrodkami włoskimi - ich zasięg ograniczał się do elitarnych kręgów dworskich ${ }^{13}$. Na początku XVI w. można jednak zauważyć nasilającą się tendencję do ksperymentowania z tym medium, wan przez wadców idostojnikow koscjowaną przez whacow id nych na terenie Rzeszy. Egzemplarze poch dzące $\mathrm{z}$ tego okresu wykonywane w pracowniach artystów północnych, są n tyle medalami w pełnym tego słowa znaczeniu, ile okolicznościowymi monetami lub wyrobami przypominającymi monety ${ }^{14}$. Za moment kluczowy, w którym ukonstytuował się i upowszechnił w cesarstwie

12 M. Gumowski, Medale Jagiellonów..., dz. cyt., s. 54-55, nr kat. 56; J.A. Szwagrzyk, dz. cyt., s. 32, gablota V,

13 Zob. U. Pfisterer, Wettstreit der Köpfe und Künste. Reprasentation, Reproduktion und das neue Bildmein Erz..., dz. cyt., s. 21-22.

man Sculpture of the Later

Cenaissance, c. 1520-1580. Art in an Age of Uncertaind. cyt., s. 22; H. Winter, Maximilian I. und das Affommen der Medaille nördlich der Alpen, w: WettAufkommen der Medaille nördlich de właściwy medal, w wariancie charakterystycznym dla krajów niemieckich, tj. o większej powierzchni, z drobiazdowo opracowanym portretem ujetym napisem w otoku na awersie i z herbami lub przedstawieniem alegorycznym na rewersie, uchodzi sejm Rzeszy zwołany do Augsburga w 1518 r. $\mathrm{W}$ jego trakcie (prace zapewne rozpoczęto nieco wcześniej) Hans Schwarz zrealizował trzydzieści jeden zamówien, wykonując ponad sto trzydzieści projektów i dostarczając prawie sto medali upamiętniających uczestników sejmu - najbardziej wpływowe osobistości w cesarstwie. W ciągu następnych lat lat medium - dotych matem przypominające monety - stało się samoistną formą reprezentacji, chętnie wykorzystywaną nie tylko przez książąt Rzeszy i hierarchów Kościoła, lecz również przez mieszczan, bankierów, humanistów i artystów. Wytworzył się popyt, który zaspokajać zaczęli wyspecjalizowani medalierzy, a wśród nich do najsłynniejszych - obok Schwarza - należeli Friedrich Hagenauer (czynny 1525-1546), Christoph WeiditzI 1523-1574) ${ }^{15}$. Medale z przedstawieniam Zysmunta I, opracowane naw a piani delu (modeli?) dostario no dostarczonego przez Hansa Schencka, ściśle - pod względem kompozycyjnym i stylowym - odpowiadają formule wypracowanej w Niemczech przez Hansa Schwarza, co dowodzi, że „eksplozja” tego gatunku, jaka nastąpiła w Rzeszy przy udziale tego rzeźbiarza po roku 1518, została zauważona w Polsce. Jednocześnie wydaje się, że zainteresowanie medalem jako nośnikiem treści propagandowych na dworze królewskim w Krakowie może mieć

15 J. Chipps Smith, dz. cyt,., s. 323-328; A. Kranz A. Riether, Kopf oder Zahl. Vervielfachte Vielfalt des Cranach - Holbein. Die Entdeckung des Menschen: Das deutsche Porträt um 1500 [katalog wystawy], hrsg. von S. Haag, Ch. Lange, Ch. Metzger, K. Schütz, 


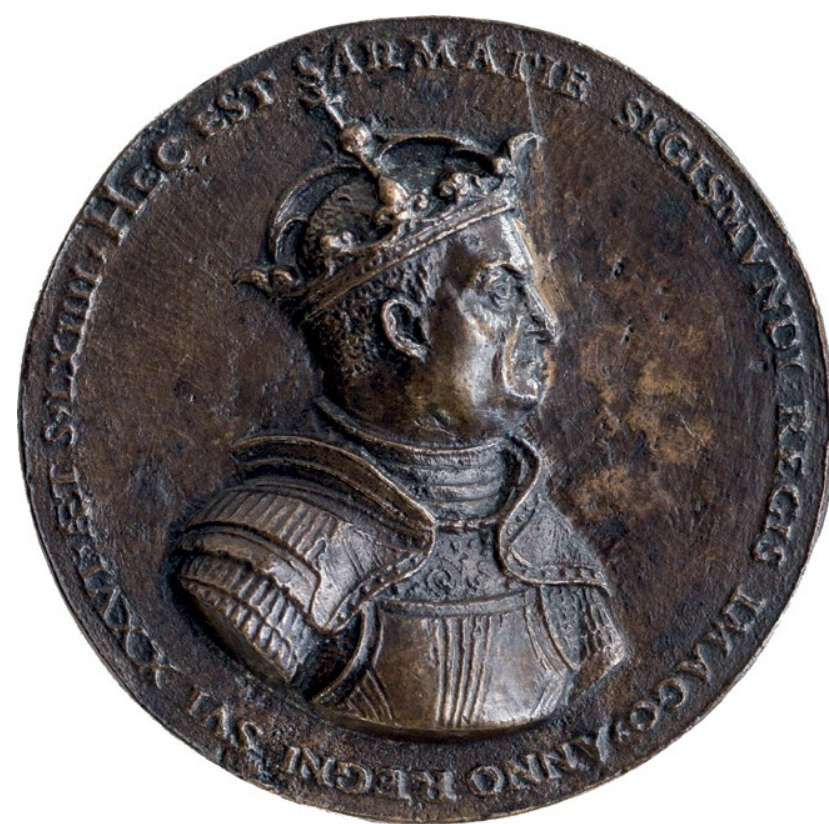

4. Christoph Weiditz I (atryb.), Medal portretowy Zygmunta I, awers, ok. 1532 r., Modena, Galleria Estense. Fot. Galleria Estense

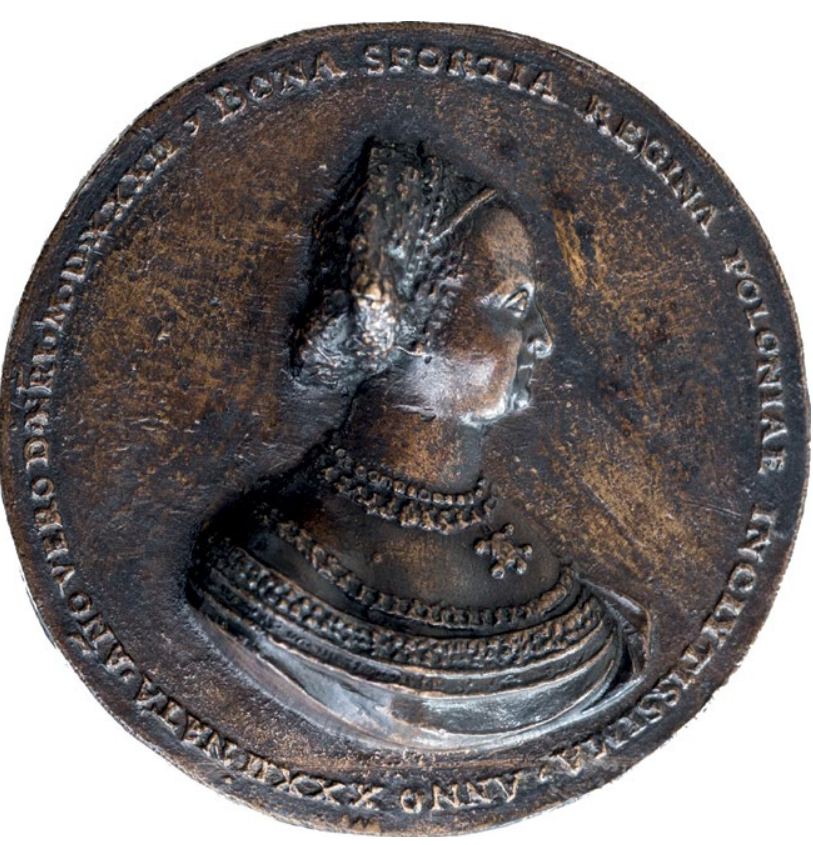

6. Christoph Weiditz I (atryb.), Medal portretowy Bony Sforzy, awers, ok. 1532 r., Modena, Galleria Estense. Fot. Galleria Estense

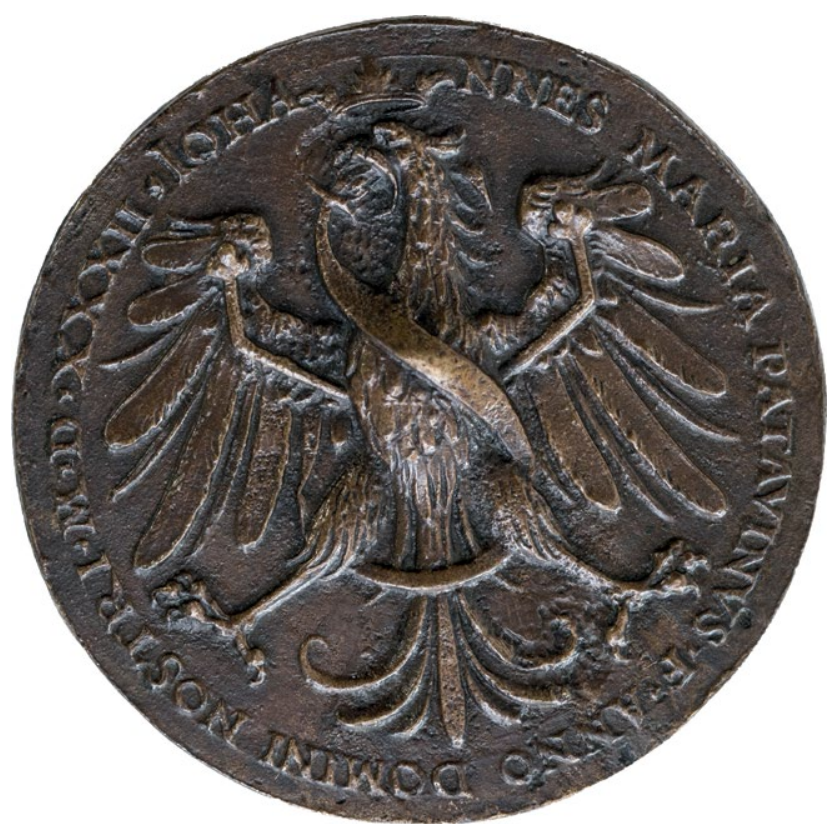

5. Giovanni Maria Mosca, zw. Padovano,

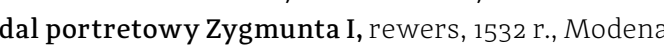
Galleria Estense. Fot. Galleria Estense

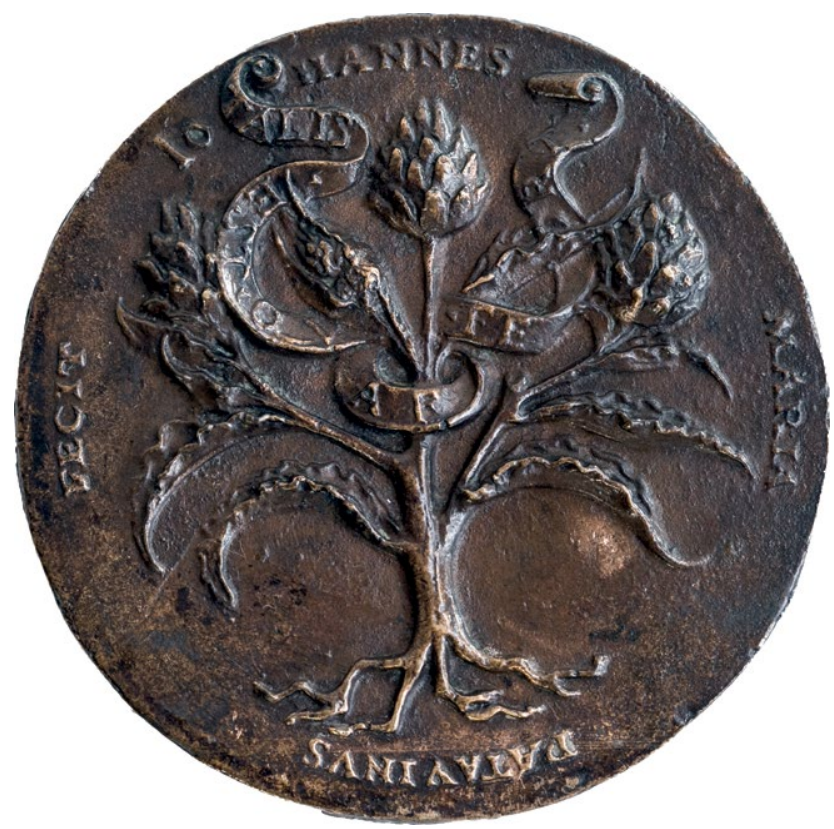

7. Giovanni Maria Mosca, zw. Padovano, Medal portretowy Bony Sforzy, rewers, 1532 r., Modena, Galleria Estense. Fot. Galleria Estense wcześniejszą metrykę, bowiem już przy okazji układu wiedeńskiego w roku 1515 od lane zostały okolicznościowe medale przedstawieniami Habsburgów i Jagiellonó $\mathrm{W}^{16}$. W kręgu Zygmunta I znane musiały też być monety z wizerunkiem Maksymiliana I bite w Halle, a nieco późnie w latach 20. XVI w., docierały do króla lane medale, tworzone na użytek następców cesarza, Ferdynanda I i Karola V ${ }^{17}$.

Medale zrealizowane w oparciu

o modele portretowe Hansa Schencka

nie są jedynymi, które utrwalały oblicze Zygmunta I. Znane są dwie serie lanych 30. XVI w. Pierwsza z nich powstała

w 1532 r. i jest sygnowana przez rzeźbiarza Giovanniego Marię Moscę, zwanego Padovanem. Oprócz medalu z Zygmuntem uwzględnia ona egzemplarze $z$ przedstawieniami Bony Sforzy, Zygmunta Augusta i Izabeli Jagiellonki. Druga, wykonana w 1538 r., wykonana została - jak sie powszechnie zakłada - przez parającego się w Polsce stównie gliptyka Ciac Ciacego sie W Polsci Caraglia. Ponadto w kierownik mennicy w Toruniu, wypuśc pierwszą serię bitych tzw. medali talarowych z przedstawieniami Zygmunta Starego i Zygmunta Augusta. W każdej z wymienionych serii wizerunek królews opracowany został inaczej, zachowując jednakowoż konwencję ujęcia popiersiowego w profilu.

Medale Padovana znane są z wielu egzemplarzy, z których najbardziej wiarygodne przechowywane są w Galerii Estense

$6 \mathrm{H}$. Winter, Medaillen auf Herrscher des ungarischen Mittelalters. Ein Beitrag zun Entwicklung der Porträt$H$. Winter, Münzen und Medaillen des ungarischen Mittelalters 1000-1526, hrsg. von M. Alram, H. Winter, Wien 2007, s. 42; U. Pfisterer, dz. cyt., s. 22.

17 Zob. H. Winter, Medaillen auf Herrscher..., dz. cyt.

s. 42; tenże, Maximilian I und das Aufkommen w Modenie, gdzie uchwytne są od roku 1838 i wedle wszelkiego prawdopodobieństwa pochodzą z kolekcji rodziny d'Este, która mogła wejść w ich posiadanie za sprawą Zygmunta I Bony Na awersach prez Zygmm one popiersia krolewskiej pary i dwojga ich najstarszych dzieci ujęte napisami w otokach. Na rewersach widnieją zaś znaki herbowe i kompozycje alegoryczne opatrzone sentencjami. Na rewersie medalu królewskiego znajduje się orzeł z torsem oplecionym literą $\mathrm{S}$ - „Sigismundus” oraz napis informujący o tym, że medal wykonał

Giovanni Maria Padovano w 1532 r..1 (il. 4-5). Odwrocie medalu z portretem Bony prezentuje krzew karczocha z banderolą opatrzoną napisem (w tłumaczeniu na język polski): „Takąż jest ta, która przynosi” (il. 6-7). Odnoszący się bez wątpienia do królowej jako matki rodzącej owoce będące królewskimi dziećmi, symbol karczocha ujęty jest inskrypcją informującą o autorstwie Padovana ${ }^{19}$. Rewers medalu z wizerunkiem Izabeli przedstawia kobietę z odsłoniętą piersią i z lewą reką wyciąonięta whierunku zwierzątka, które moźna zidenwyfikowac dzięlinapisowi wozinaziden-

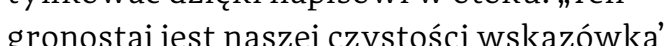
(il. 8-9) Ob noz jzystosci wskazówką" (il. 8-9). Obok niewiasty znajduje się także pień, z którego wyrasta ulistniona gałązka. Wypada ją interpretować, w ślad za ustaleniami Mieczysława Morki, jako alegorię Izabeli, traktowanej jako świeża gałą́ zaszczepiona dzięki Bonie na pniu rodu Jagiellonów. Pod całą kompozycją znajduje się skrócony napis informujący

18 M. Gumowski, Medale Jagiellonów..., dz. cyt., s. 63, nr kat. 65; M. Morka, Sztuka dworu..., dz. cyt., s. 322

3, s. 18 loprac M. Zawadzki.

19 M. Gumowski. Medale Jagiellonów.... dz. cyt. s. 63-65, nr kat. 66; M. Morka, Sztuka dworu..., dz. cyt.. s. 397-400; tenże, The Beginning..., dz. cyt., s. 68-72; ostatnio Medale polskie..., dz. cyt., nr 4, s. 19 (oprac. 


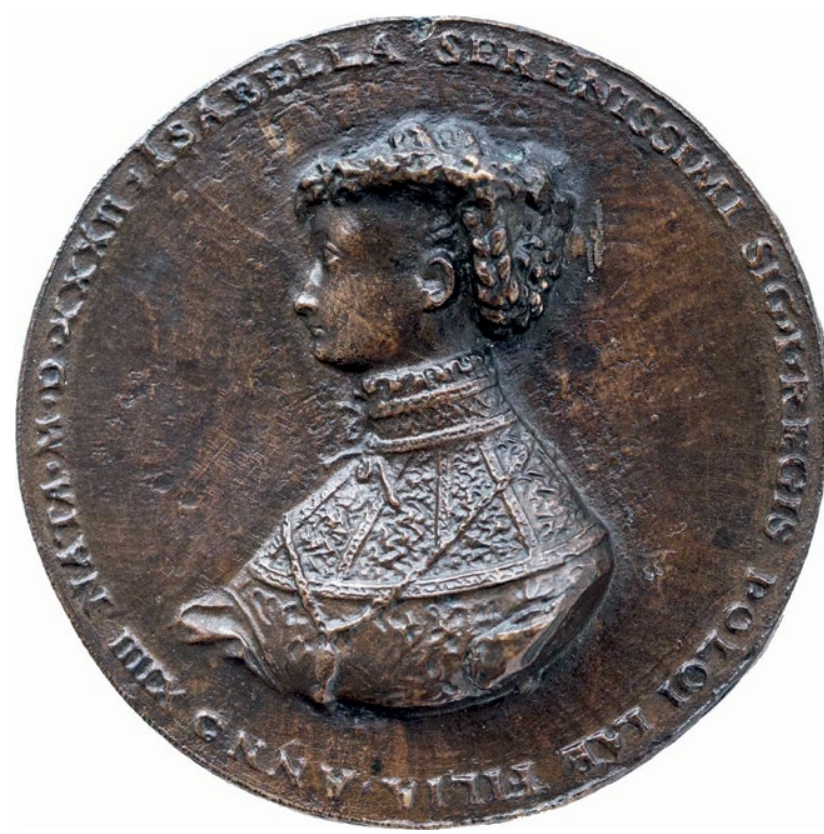

8. Christoph Weiditz I (atryb.), Medal portretow Izabeli Jagiellonki, awers, ok. 1532 r., Modena,

Galleria Estense. Fot. Galleria Estens

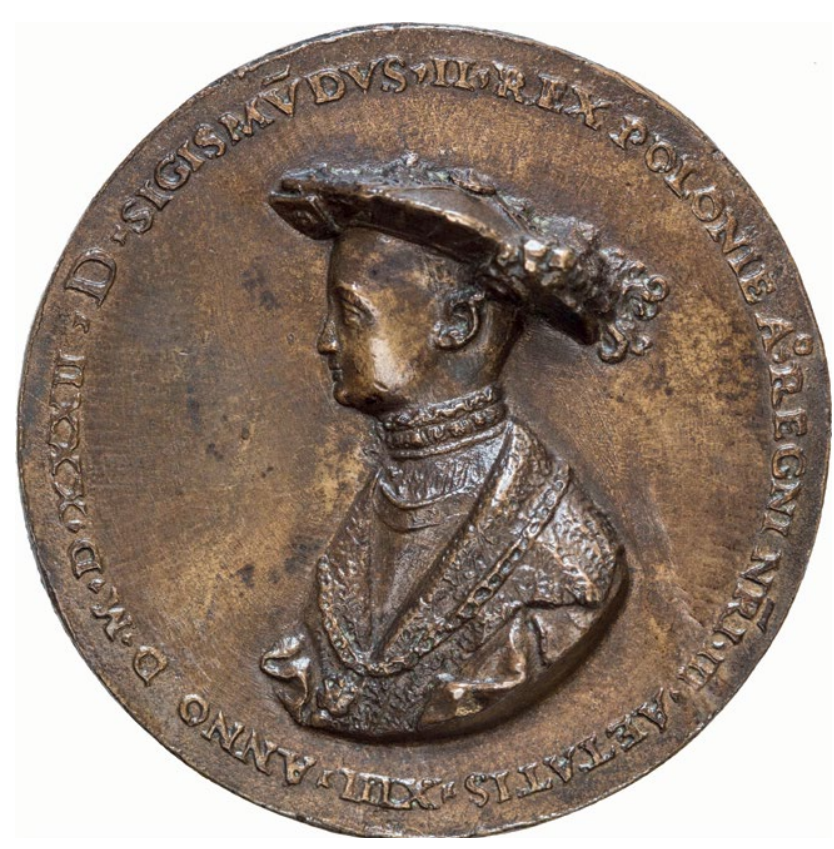

o. Christoph Weiditz I (atryb.), Medal portretowy Zygmunta Augusta, awers, ok. 1532 r., Modena,

Galleria Estense. Fot. Galleria Estens

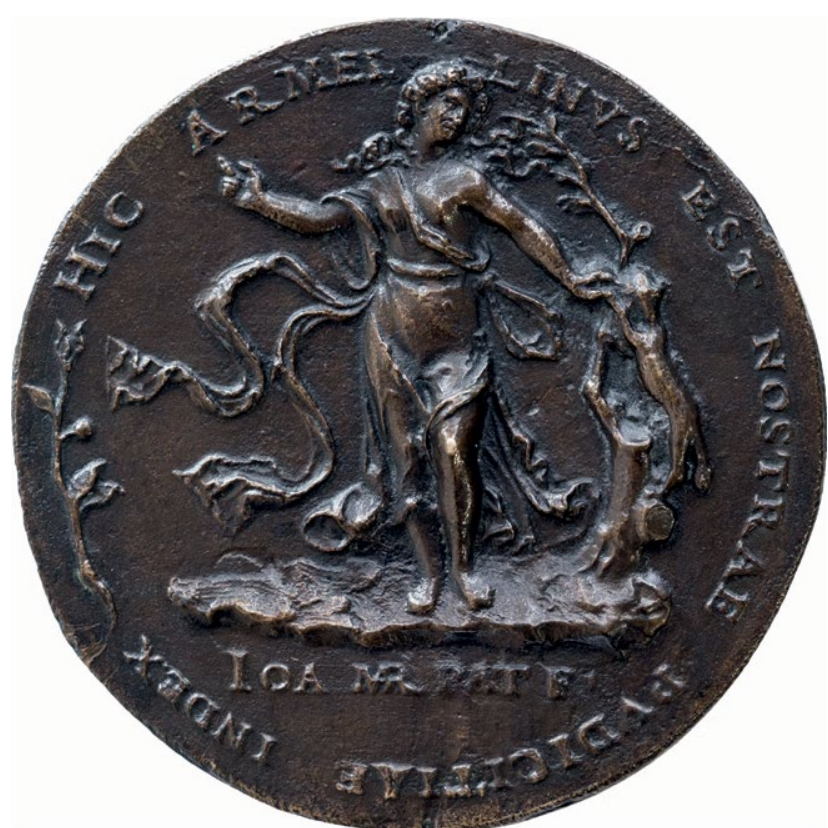

9. Giovanni Maria Mosca, zw. Padovano, Medal portretowy lzabell aglellonki, rewers, 1532 r Modena, Galleria Estense. Fot. Galleria Estens

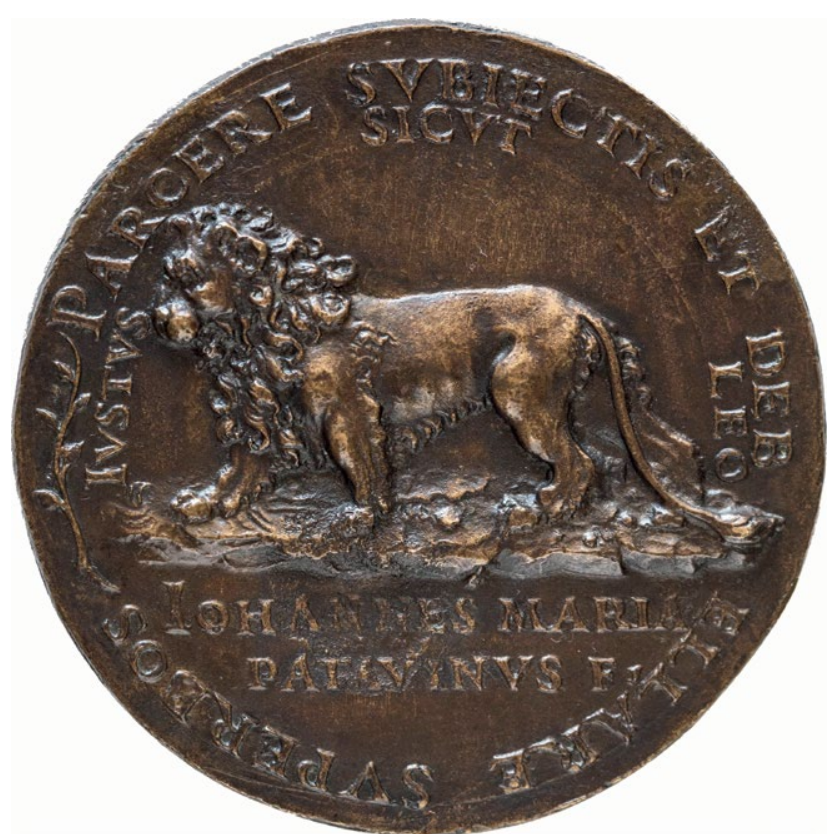

11. Giovanni Maria Mosca, zw. Padovano, Medal portretowy Zygmunta Augusta, rewers, 1532 Modena, Galleria Estense. Fot. Galleria Estens o autorstwie Padovana ${ }^{20}$. Medal z przedstawieniem Zygmunta Augusta, ozdobiony został na odwrociu figurą stąpającego lw pod którym, podobnie jak na medalu Izabeli, zlokalizowano sygnaturę artysty (il. 10-11). W otoku znaiduje się napis (w ttumaczeniu na język polski): „Przebaczać pokonanym, a pokonywać pysznych” zapożyczony z Eneidy, a w wewnętrznym górnym półotoku inskrypcja: „Sprawiedliwy jak lew". Całość prezentuje zatem następce Zygmunta na polskim tronie w zwierciadle cnót łaskawości i sprawiedliwości i przedstawia go nie tylko - jak pisał Morka - jako króla w po ne", Agniesza Smolucha-Stadkowska-nawiazuje do figury krola Salom zuje do fgury keola Salomona oraz Psalmu 72 (71), którego pierwszy werset zdobi architraw ściany tronowej kaplicy

Zygmuntowskiej ${ }^{21}$. Treść inskrypcji i kompozycji alegorycznych na wszystkich czterech medalach nie zostawia wạtpliwości, że wyrażają one idee zgodne z intencjam Zygmunta I i Bony. Co więcej, zawarta

w nich tytulatura posługuje się określeniami znanymi z wcześniejszych fundacji artystycznych Jagiellonów (np. Sarmatiae rex w odniesieniu do Zygmunta Starego, divus w odniesieniu do młodocianego Zygmun Augusta), co oznacza, że program medali został opracowany przez kogoś ze ścisłego kręgu dworu królewskiego w Krakowie. Intencjonalne są bez wątpienia także nieścisłości w informacjach o wieku Bony,

20 M. Gumowski, Medale Jagiellonów..., dz. cyt., s. 66-69, nr kat. 68; M. Morka, Sztuka dworu..., dz. cyt., s. 417-418; tenze, The Beginning..., dz. cyt., s. 72-74. 11 M. Gumowski, Medale Jagiellonów..., dz. cyt., s. 65 , nr kat. 67; M. Morka, Sztuka dworu..., dz. cyt., A. 412-416; tenze, The Beginning..., dz. cyt., s. 74-78; Zygmunta Augusta autorstwa Padovana, w: Medal imedalierstwo na przestrzeni wieków, red. taż, P. Taradaj, M. Woźniak, Kraków 2019, s. 47-50. Zob. także Medale polskie..., dz. cyt., nr 5, s. 20-21 (oprac.
Izabeli i Zygmunta Augusta, stwierdzone w napisach na awersach ich medali. Bona została przedstawiona jako urodzona lat temu 32", podczas gdy w chwili wykonania medalu miała lat 38 , Izabela i Zygmunt August zaś są postarzeni o rok - Izabela, pomimo że w 1532 r. miała 13 lat, w inskrypcji jest przedstawiona jako czternastolatka, Zygmunt August, chociaż miał w tym roku 12 lat, na medalu jest przedstawiony jako trzynastolatek. W starszej literaturze uważano, że nieścisłości te były omyłkami świadczącymi o wykonaniu medali z dalek od krakowskiego dworu22 Jedynie Anne Markham Schulz była skłonna przyjąć, że zmiany, w których rodzicom ujęto lat, a dzieciom dodano, były celowe ${ }^{23}$. W istocie można przypuszczać, że przeprowadzono tu manipulację wiekiem sportretowanyc osób, by wykazać pomyślność domu

Jagiellońskiego. Nieprzypadkowo bowiem data urodzin Bony przypada na rok święty 1500, a daty narodzin dzieci - Izabeli (rzekomo 1518) i Zygmunta Augusta (rzekomo 1519) wypadają bezpośrednio po ślubie

z Zygmuntem Starym. Zmodyfikowane daty narodzin Bony i jej dzieci mają utwierdzać w przekonaniu, że oto mamy do czynienia ze pzczélinym zról manim do czynienia cieszącym sie wspaniałym potomstwem, i z królewskim rodem pozostającym pod Bożą opieką.

$$
\text { Kwestiami otwartymi pozostają }
$$

wciąż autorstwo omawianych medali

\section{Zob. J. Eckhardtówna, Potrzeby nauki polskiej} plastyki renesansowej, ,Sprawozdania Poznańskieso Towarzystwa Przyjaciół Nauk", r. 12, 1938 (1939), s. 43-44; J. Grabski, Le immagini del re di Polonia Sigismondo re della Famiglia reale sulla serie di medaglie del 1532 di G.M. M. Mosca detto il Padovano ne
collezione già estense a Modena, w: Italia, Venezia e Polonia tra Medio Evo e età moderna, ed. V. Branca, S. Graciotti, Firenze 1980, s. 573, 583-584; M. Morka, Sztuka dworu..., dz. cytt., s. 398, 417.

23 A. Markham Schulz, Giammaria Mosca, called Padovano: a Renaissance sculptor in Italy and Poland 


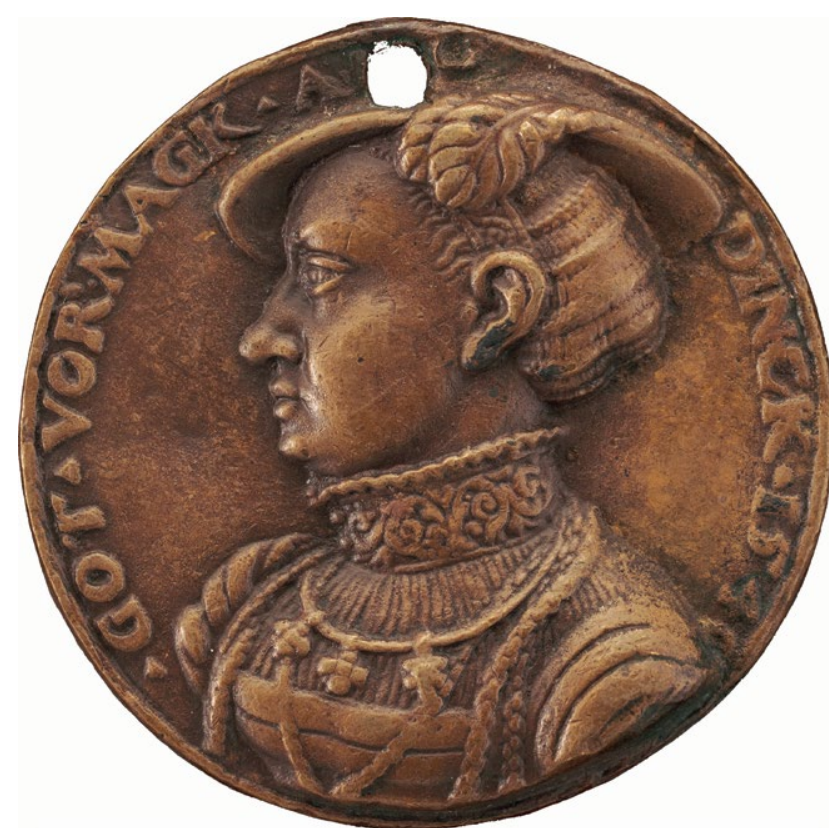

12. Christoph Weiditz ( (atryb.), Medal portretowy Emilii Saskiej, $1540 \mathrm{r}$ r., Waszyngton, National Gallery of Art. Fot. National Gallery of Art

i miejsce ich wykonania. Większość badaczy zwracała uwagę na nieprzekonujące pod względem mimetycznej poprawności portrety Jagiellonów, przychylając się do opinii, że odlane one zostały poza Krakowem. Podpisany na rewersach wszystkich czterech medali Giovanni Maria Mosca uchwytny jest w Padwie po raz ostatni w roku 1529, następnie zaś notowany jest w czerwcu 1533 r. w związku z pracami nad cyborium fundacji biskupa Piotra Tomickiego dla katedry krakowskiej ${ }^{24}$. Medale opatrzone datą 1532 mogły zatem, lecz nie musiały być wykonane

w Krakowie. Anne Markham Schulz zauważyła ponadto brak relacji między awersami i rewersami medali, dochodząc do wniosku, że Padovano był jedynie autorem tych ostatnich ${ }^{25}$. Uzasadniając swój pogląd, stwierdziła brak analogii do omawianych dzieł wśród medali włoskich oraz takie

24 Tamże, s. 96-97; M. Morka, The Beginning..., dz. cyt. S. 78

25 A. Markham Schulz, dz. cyt., s. 122-124 cechy, jak nieproporcjonalnie małe litery, niespotykany we Włoszech wysoki relief, rentne osadzenie popiersi w polach meda ibłędy perspektywiczne. Jej zdaniem miało o świadczyć o tym, że autorem awersów był rzeźbiarz krakowski, niewyspecjalizowany w medalierstwie, o innej wrażliwośc artystycznej niż Padovano ${ }^{26}$

Spostrzeżenia Markham Schulz wydają się po części trafne - krój liter w otokach awersów jest różny od tych na rewersach, a sposób opracowania portretów Jagiellonów jest wistocie nieprzystający do włoskiej tradycji medalierskiej: popicy do whosk jepiersia ystęua daleko przed lico powierzchni medali, znacząco kontrastując z medalami włoskimi, które operują z reguły płytszym reliefem. Trudno też nie zauważyć różnic w skali poszczególnych reliefów i tego, że nie wypełniają one dokładnie pól awersów. Wypada zatem przyjąć, że podpisane przez Padovana medale są tylko częściowo jego dziełami: rewersy wyszly spod jego je dziełani. rewersy wyszły spod jego wat lecz awersy odlat on w oparciu o. go. Kim zatem byl domniemany autor awersow medali sygnowanych przez Padovana? Najbliższe im pod względem stylowym wydają się medale powstałe w kręgu artystów niemieckich, związanych z Augsburgiem lub Norymbergą, w szczególności zaś medale Christopha Weiditza I, wspomnianego już rzeźbiarza, który zaliczał się do pierwzzeso pokolenia twórców profesjonalnie jajmująch się produkcją medali szę ale. Sposród ok. stu pięc dziesięciu przypisywanych mu medali większość przedstawia portretowane postacien trois quarts w szerokim popiersiu. Można jedna

26 Tamże, s. 124. Por. M. Stahr, Zygmunt August, 1532 w: Medale polskie iz Polska zwigzane od XVI do XV wieku. Katalog zbiorów Muzeum Narodowego w Poznaniu, t. 11, oprac. taż, Poznań 2008, s. 26-27 oraz Medale polskie..., dz. cyt., s. $16-17$ (gdzie

(a)
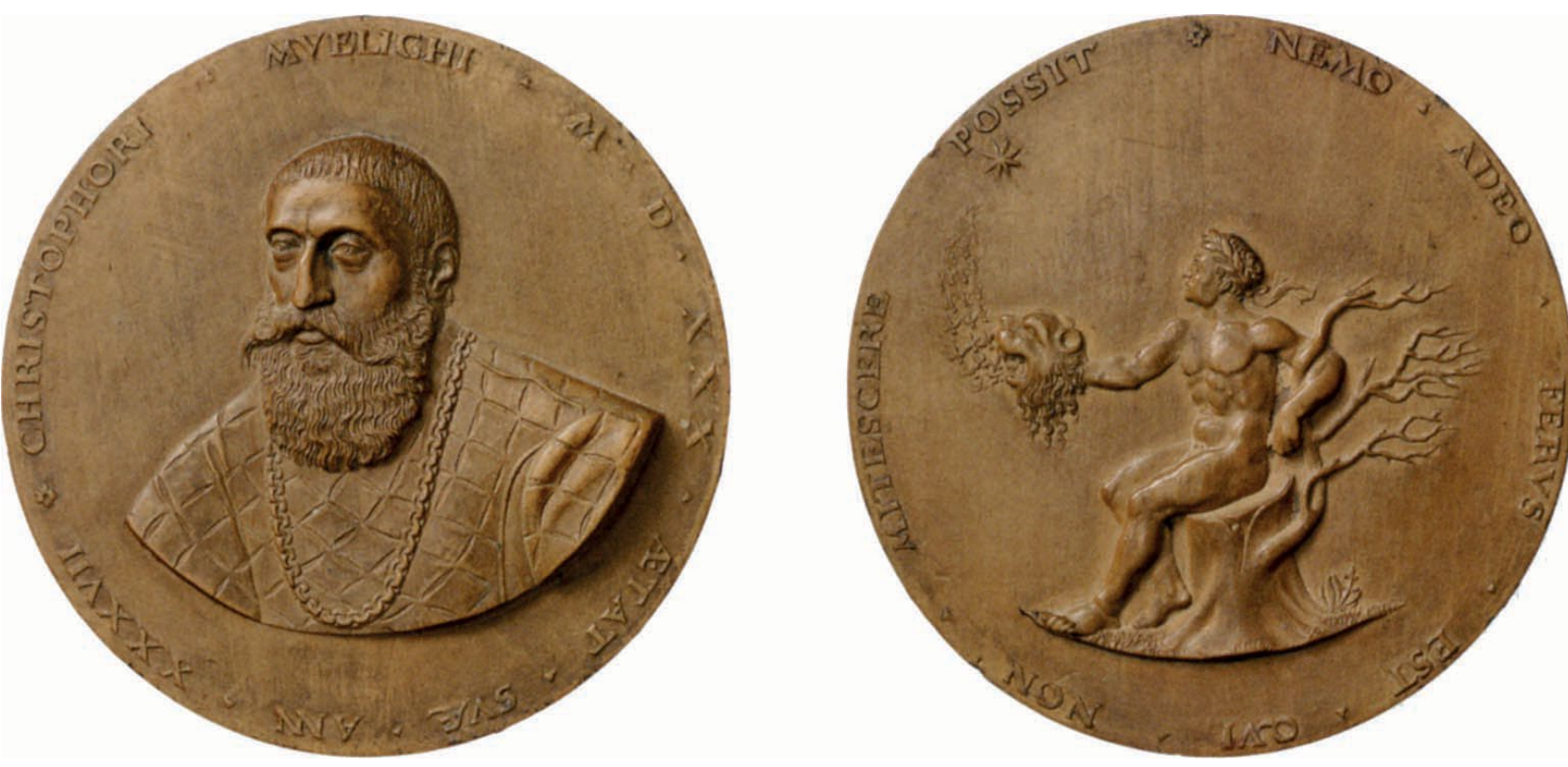

13. Christoph Weidtz1, Model medalu portretowego Chrstopha Mülicha, awers i rewers, 1530 r., Berlin, Staatliche Münzsammlung. Fot. wg Wettstreit

wskazać takie, które operują ujęciem profilowym.

Wizerunki Bonyi Izabeli z kolekcji w Modenie można na przykład porównać do medalu Emilii Saskiej, córki Henryka IV, księcia Saksonii, i żony Grzegorza Pobożnego, margrabiego Brandenburskiego ${ }^{27}$ (il. 12). Wykonany w 1540 r. medal powstał przy zn jomości portretu Emilii wykonanego w 1535 przez Lucasa Cranacha St. Z dziełem tym omawiane medale jagiellońskie łączy podobny sposób opracowania twarzy (zwłaszcza w partii oczul oraz ujęcie postaci, w którym głowa ukazana jest w profilu, a ramiona zwrócone w trzech czwartych. Co szczegó nie istotne, znakomita większość medali nie istotne, znakomita większośc medali wo głęboko ciętym reliefie - identycznym

\section{G. Habich, Die deutschen Schaumünzen..., dz. cyt., Bd. 2 Cats Museum, Gloucester 1990, nr kat. 185; J. Graham Pollard, Renaissance Medals. The Collection of the} National Gallery of Art, Systematic Catalogue, vol. 2, z tym, w którym wykonano omawiane portrety Jagiellonów. Styl ten wynikał w znacznym stopniu z tradycji warsztatowej artysty, nawykłego do pracy w drewnie i zazwyczaj w tym materiale opracowującego modele do odlania ${ }^{28}$. Również zauważon przez Markham Schulz niedokładne osadzenie popiersi w polach medali znajduje analogie w twórczości Weiditza. Jako przykład można przywołać jego medale wykonane w latach 1533 i 1534 dla Christopha Mülicha, kupca w służbie rodziny Fuggerów. Przedstawiony na nich portret Mülicha w bogatym stroju i łańcuchu na piersi nawiązuje do drewnianego modelu medalu sporządzonego $\mathrm{w} 1530 \mathrm{r}$. $\mathrm{z}$ popiersiem na awersie i alegoryczną kompozycją z Samsonem na rewersie ${ }^{29}$ (il. 13). Kompozycje

28 Zob. M. Teget-Welz, Biographien der Medailleure, w: Wettstreitin Erz..., dz. cytt.s. s. 335; H. Maué, Augsburg Por. J. Chipps Smith, dz. cyt., s. 332

29 Zob. W. Cupperi, Beyond the Notion of German Medals. Some Cases of Transnational Patronage, w: Wetts 
na obu stronach tego modelu charakteryzuje podobne jak na medalach jagiellońskich zachwianie proporcji i nierównomierne osadzenie reliefów w polach.

Przywołany model z przedstawieniem augsburskiego kupca jest istotny takż z innego względu. Jest on mianowicie, wedle wszelkiego prawdopodobieństwa, tożsamy z medalem (Medallia), o którym jest mowa w korespondencji między Christophem Mülichem a Janem Dantyszkiem, podówczas ambasadorem polskim na dworze cesarza Karola V. W liście z 6 marca 1531 r. Mülich zwracał się z prośbą do Dantyszka, aby zechciał upomnieć rzeźbiarza

Krzysztofa [Weiditza - M.G.], sługe Waszej Miłości, by mi wreszcie mój medal wykończył. Co gdy się stanie, proszę go wziąć do siebie, wytargować i za pośrednictwem Ulryka Oehringera lub Wolfa Hallera przesłać" ${ }^{30}$. Wynika z niego, że Dantyszek, bawiący w tym roku razem z cesarskim dworem w Brukseli, był w bliskim kontakcie z Weiditzem, który wykonywał dla niego $z$ Weiditzen cie znane są trzy medale Dantyszka wykonane przez Weiditza w latach 1529-1531. Dwa wcześniejsze powstały w związku z nadaniem mu szlachectwa hiszpańskiego i dodani do herbu dwóch orlich skrzydeł przez Karola V. Trzeci, wykonany w 1531 r., został zamówiony po otrzymaniu przez biskupstwa chełmińskiego w roku $1530^{31}$. Ten ostatni, przesłany na recce Bony, znany jest z często przywoływanej w literaturze opini królowej, zapisanej w liście jej dworzanina Fabiana Wojanowskiego, który 22 listopada

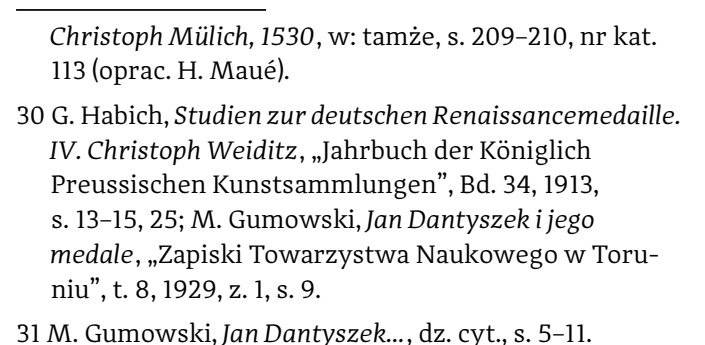

1531 r. donosił Dantyszkowi, że „rozprawialismy tutaj dużo o wizerunku Przewielebności rokrotnie wszystkim i wszyscy, zarówno jej krón , p. Niszczy, Golcz i ja, twierdzili, że 列 naliby, kogo przedstawia"

W istocie, w okresie w którym powstały wzmiankowane medale Dantyszk i z którego pochodzi przywołany list, Weiditz pozostawał w ścisłym kręgu cesarskiego dworu, z którym jako złotnik przemieszczał się od Portugalii i Hiszpan Whoczy i Nidera Włochy iNiqenla dy. Wán ych wykonywał medale, znajdowali się zarówno przedstawiciele możnowładztwa wysoko postawionego duchowieństwa z terenów Rzeszy, jak i europejscy władcy ${ }^{33}$ Można sobie zatem wyobrazić, że zaprzyjaźniony z Dantyszkiem rzeźbiarz, wyspecjalizowany w produkcji małoformatowych portretów, mógł wykonać dla niego medale lub ich drewniane modele z przedstawieniami czlonków rodziny Jagiellón, nawetjemi in jezeli nie są one wsponinane wachowanym materiale źródłowym. Zaproponowana tu atrybucja - rzecz jasna hipotetyczna i wymagająca weryfikacji - rzucałaby też pewne światło na okoliczności wykonania rewersów przez Giovanniego Marię Moscę.

Medale Jagiellonów, zapewne jednostronne, jeżeli rzeczywiście zostały wykonane przez Weiditza, musiały być przesłane przez lecz w oparciu ónód pośrednie-przedstawienta jagiellowow zojduące siępotencjalnie w posiadonów znajdujące się potencjalnie w posiadaniu Dantyszka, względnie nnych osób związanych z dworem cesarza Karola V ${ }^{34}$. To tłumaczyłoby ich stosunkowo

Tamì, s. 14

33 Zob. M. Teget-Welz, Biographien..., dz. cyt., s. 334-33 34 Władystaw Pociecha podaje frapuiącą informację
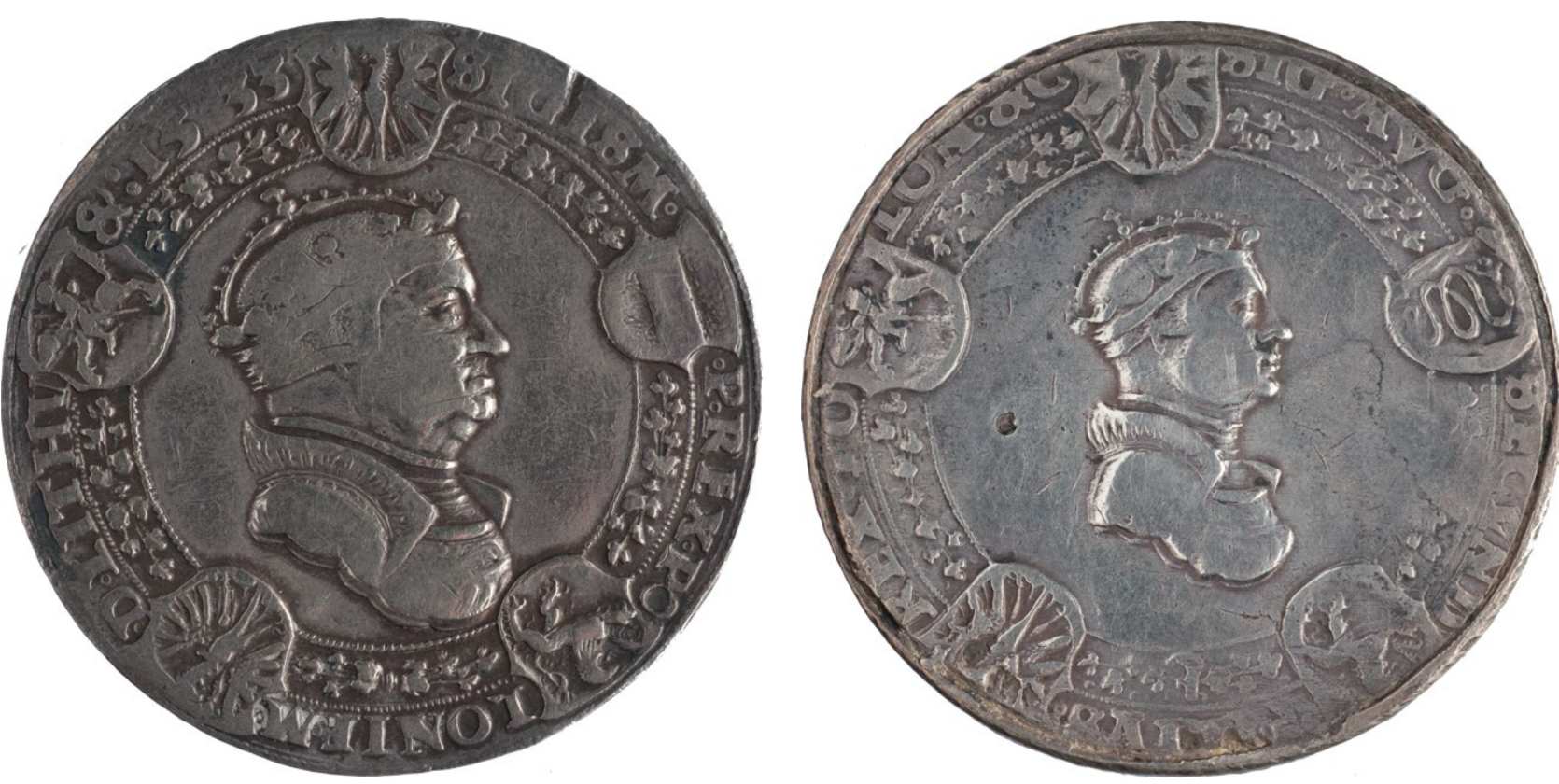

14it5. Maciej Schilling, Talar medalowy Zygmunta i, awers i rewers, 1533 I

Muzeum Narodowe w Krakowie. Fot. MNK

ogólny charakter, w którym większy nacisk położony jest na pokazanie wyidealizowanego obrazu króla i członków jego rodziny niż pieczolowite odnotowanie szczególów ich twarzy. Kraków wobec powyższego wydaje się najlepszym miejscem dla sporządzenia alegorycznych rewersów i połączenia ich z portretowymi medalami. Przy takim scenariuszu należałoby przyjąć, że W 1532 r. świeżo przybyły do miasta Mosca podjął się zlecenia od kröla lub krolowej, polegającego na uzupełnieniu nadesłanych przez Dantyszka medali. Opatrzenie przez niego każdego z medali whasną sygnaturą niego kazdego z me al wą sygnaturą jastomy udowania autorytetu w nieznanym, elitarnym środowisku jagiellońskiego dworu. Znaczący jest również fakt, że ukończone medale młody artysta podpisał nie swoim nazwiskiem lecz przydomkiem Patavinus identyfikującym go

zabeli. Miały one zostać przez Bonę przekazane posłom Karola V, którzy w październiku 1525 r. gościl w Krakowie, by podarować Zygmuntowi Order Złotego Runa. W. Pociecha, Królowa Bona (1494-1557) jako Włocha, przydomkiem, który nie występuje na jego wcześniejszych dziełach, a ktorym od tej pory konsekwentnie sygnoał dzieła wykonane w Polsce ${ }^{35}$.

Jak wyżej zasugerowano, omówione medale Jagiellonów - jeżeli rzeczywiście zostały wykonane przez Weiditza - musiały powstać w oparciu o jakieś wzory ikonograficzne, być może malowane portrety. Świadczy o tym samo oblicze Zygmunta I, które - jakkolwiek nie ma takiej siły wyrazu, jak fizjonomia utrwalona na medalach Schencka - zachowało podstawowe cechy wyglądu monarchy znane z wcześniejszych wizerunków Co zzczegine wczesniejszyc wizerdu zentue ono nowy wariant kroblewskego portretu, który znany jest przynajmniej z dwóch innych realizacji pochodzących ze zbliżonego okresu. Zaprezentowano w nim króla w heroizowanej konwencji władcy zbrojnego - Zygmunt Stary przedstawiony został w płytowej, renesansowej zbroi oraz z koroną zamkniętą nałożoną na odkrytą głowę.

35 A. Markham Schulz dz cyt, s-96-97. 
Do tego samego wariantu nawiązują portrety Zygmunta I i Zygmunta Augusta, zdobiące odpowiednio awers i rewers okolicznościowego talara medalowego, wybitego w srebrnych go w srebrnych izlotych egzemplarzach w mennicy kroblewskiej w Toruniu w ro 1533 przez Macieja Schillinga ${ }^{36}$ (il. 14-15). Pełna godności głowa króla w czepcu i sklepionej koronie oraz odpowiadające jej oblicz młodocianego Zygmunta Augusta unaoczniają królewski autorytet obu Jagiellonów, wzmocniony koronacją królewicza przeprowadzoną vivente rege $\mathrm{w} 1530 \mathrm{r}$. Oba wizerunki mają charakter oficjalny - prezentuja runki dorze ich królewskilej wladzy jako takie posłużyty za wzór dla portretów obydwu Zygmuntów, wykonanych przez Melchiora Baier w oparciu o modele autorstwa Petera Flötnera i umieszczonych na predelli srebrnego ołtarza w kaplicy Zygmuntowskiej, ukończonego w 1538 r. ${ }^{37}$

Przy znajomości talarów medalo-

wych Schillinga musiał powstać także medal z przedstawieniem Zygmunta Iopatrzony data 1538 . Medal ten znany jest

zasadniczo z dwóch egzemplarzy odlanych w złocie, jednego przechowywanego

w Zakładzie im. Ossolińskich we Wrocławiu (il. 16-17) i innego, znajdującego się w Cabinet des Médailles w Bibliothèque Nationale

w Paryżü ${ }^{38}$. O zależności od talara Schillinga świadczą proporcje twarzy postarzałego króla i wiele szczegółów, takich jak zaostrzony profil nosa mięsista dolna warga oraz wystający podbrólekiobwise podgarle.

36 M. Gumowski, Medale Jagiellonów..., dz. cyt., s. 69-72, tenże, The Beginning stza dw

37 M. Morka, Sztuka dworu..., dz. cyt., s. 221; tenże,

38 M. Gumowski, Medale Jagiellonów..., dz. cyt., s. 75-77, nr kat. 73; tenże, The Beginning,..., dz. cyt., s. 82; 1. Wojciechowski, Caraglio w Polsce, ,Rocznik Histon
Sztuki", r. 42, 2000, nr 25, s. 42-43, nr kat. i; tenże, Caraglio, Warszawa 2017, s. 354-355, nr kat. 77, starsza literatura tamże.
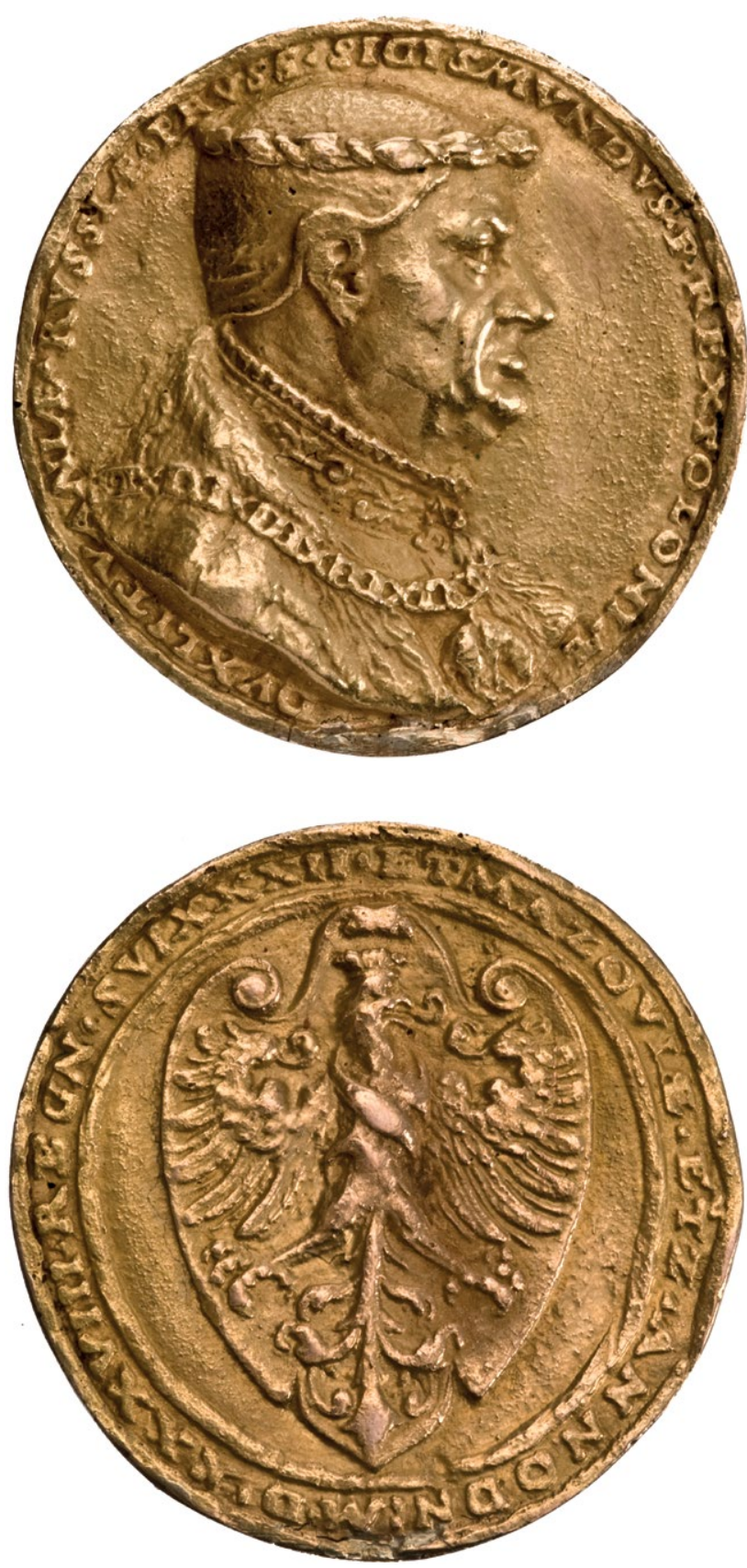

16i 17. Matthes Gebel, Medal portretowy Zygmunta I, awers i rewers, $1538 \mathrm{r}$., Wrocław, Zakład Narodowy im. Ossolinskich. Fot. ZNiO
Chociaż na medalu tym ukazano Zygmunta w stroju „codziennym”, tzn. w płaszczu futrzanym narzuconym na marszczoną koszule z wysokim kołnierzem, a nie w zbroi, zachowano charakterystyczny czepiec, znany z monet Schillinga i portretu na predelli ołtarza srebrnego. Zauważyć jednak trzeba, że autor medalu nie podążał bezwiednie za podstawionym mu wzorem, lecz stworzył dzieło w zupełności samodzielne. Twórczo przekształcając kompozycje

Schillinga, dostarczył dobrze przemyślany i znakomicie wykonany medal z portretem o zdumiewającej sile wyrazu. Drobiazoowe opracowaie detali, sugerujące ka, oraz dat ka, oraz data powstanla medalu, zblizona do czasu przybycia Caraglia do Polski, spowodowały, że uznawany jest on w literaturze za dzieło tego włoskiego artysty ${ }^{39}$. Wedle wszelkiego prawdopodobienstwa Caraglio przybył do Polski na przełomie $153811539 \mathrm{r}$ polecony królowej Bonie przez Alessandra Pesentiego (pochodzącego z Werony, nadwornego organisty $i$ najukochańszego muzyka" Bony), a może też przez Pietra Aretina, humanistę i poetę włoskiego, którym królowa utrzymywała kontakt korespondencyjn $y^{40}$.

$$
\text { Monografista Caraglia, Jerzy }
$$

Wojciechowski, sugeruje, że królewski medal mógł powstać w Wenecji, niedługo przed wyjazdem artysty do Polski, jako próbka jego umiejętności sporządzona w czasie starań o uzyskanie przychylności monarchy. Faktem jest, że Caraglio wykonywal med Whótce po przybyciu do kraju wal medale. Wkotce po przybyciu do kraju niezachowany medal królowej Bony. niezachowany medal królowej Bony. Przypisywany mu jest także inny meda
portretowy Bony z roku 1546 oraz dwa

39 Zob. J. Wojciechowski, Caraglio w Polsce..., dz. cyt. s. 37, 42; tenże, Caraglio..., dz. cyt., s. 90,354
M. Morka, The Beginning..., dz. cyt.s. 82 .

M. Mork, The Beginning..., dz. cy., s. 82. 40 J. Wojciechowski, Caraglio w Polsce..., dz. cyt., s. 25-27, medale Zygmunta Augusta ${ }^{41}$. Jednak - jak zauważył sam Wojciechowski - autorstwo omawianego medalu Zysmunta I stoi pod znakiem zapytania. Istotnie już Jan Bołoz Antoniewicz dostrzegat w nim rękę nie Anieciewiez dostrzega wa nim reke niebył skłonny uznać au Martwo Gumowski żymi zastrazze au ży nizzstrezeniami, pisząc, że jest to przekonanie subiektywne, „poparte chyba tylko faktem, dosyć chyba względnym, że medal taki jak on jest, mógł wyjść tylko z ręki pierwszorzędnego złotnika"43. W rzeczy samej, podobnie jak w przypadku medali sygnowanych przez Padovana, również w odniesieniu do tego medalu można pokuić się o hipotetyczna rewizje jego auto stwa. Szereg cech kompozycyinychi drobniejszych szczegółów łączy bowiem i to dzieło z wyrobami twórców niemieckich, w szczególności zaś norymberskich: Matthesa

Gebela i Petera Flötnera. Ogólna kompozycja awersu medalu, sposób osadzenia popiersiowego przedstawienia króla w polu oraz krójliter w napisie otokowym przypominają wiele kompozycii Gebela z lat 30. i 40 XVI w. takich na pryltad, jak nedale: i 40. XVI w., takich na przykład, jak med młodocianego margrabiego Albrechta Alcybiadesa Brandenburga z 1534 r. ${ }^{44}$, Ludwika X, księcia Bawarii z roku $1535^{45}$ (il. 18) i Katarzyny Holzschuher z roku $1536^{46}$ (il. 19). Ten ostatni wart jest uwagi także dlatego, że na kołnierzu portretowanej można dostrzec wzór z dwóch spiętych ze sobą i zawiniętych antytetycznie ślimacznic który występuje na taśmie zdobiącej kołnierz koszuli Zygmunta.

41 Zob. tenżè, Caraglio w Polsce..., dz. cyt., s. 38; tenże, Caraglio.., dz. cyt., s. 89-96.

42 J. Bołoz Antoniewicz, Lament Opatowski i jego twórca,

43 M. Gumowski, Medale Jagiellonów..., dz. cyt., s. 77.

44 G. Habich, Die deutschen Schaumünzen..., dz. cyt., Bd. 1,

45 J. Graham Pollard, dz. cyt., nr kat. 728 46 G. Habich, Die deutschen Schaumünzen..., dz. cyt., Bd. 1 . 


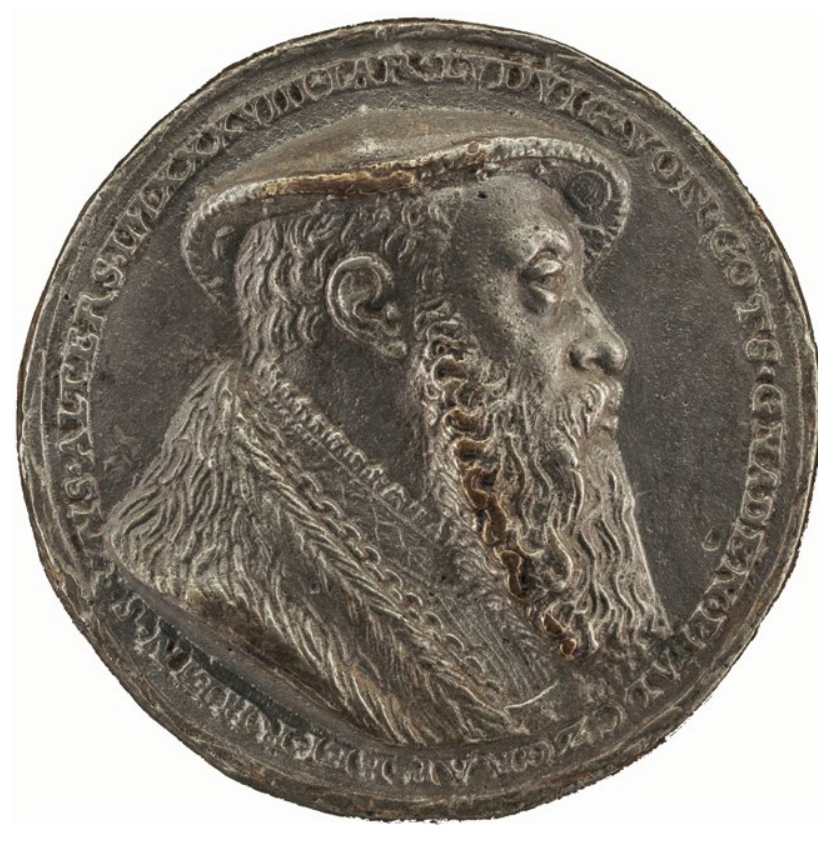

18. Matthes Gebel, Medal portretowy Ludwika X, księcia Bawarii, 1535 r., Waszyngton, National Gallery of Art. Fot. National Gallery of Art

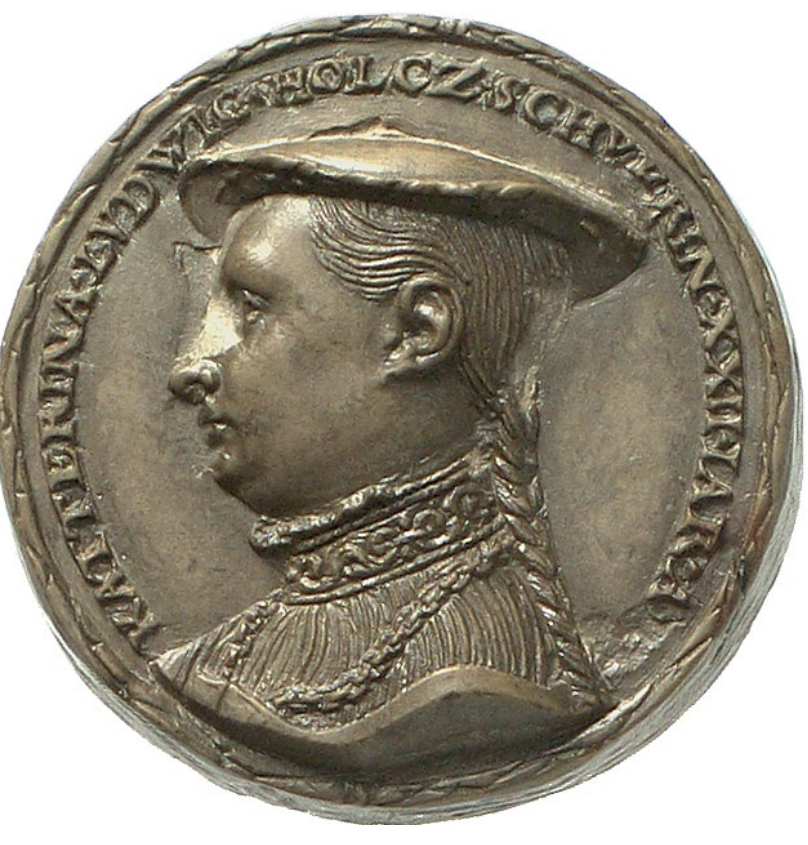

19. Matthes Gebel, Medal portretowy Katarzyny Holzschuher, 1536 r., Berlin, Staatliche Museen. Fot. Staatliche Museen w wapieniu z Solnhofen, odznaczają się niezrównaną biegłością techniczną ${ }^{48}$. Typowe dla tego artysty jest drobiazgowe opracowywanie elementów stroju i predylekcja do urozmaicania fizjonomii portretowanych osób - a więc te cechy, które charakteryzują przedstawienie na omawianym medalu. Wypada również wspomnieć, że Gebel już wcześniej, ok. roku 1528, wykonał niewielki medal z przedstawieniem Zygmunta I, który

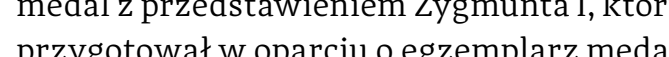
przygotował w oparciu o egzemplarz medalu autorstwa Hansa Schencka ${ }^{49}$. Peter Flötner z kolei, pracujący w Norymberdz od 1522 r. jako Schittzer, znany jest jako twórca projektów dla wielu dzieł drobnej rzeźby i złotnictwa, spośród których srebrny ołtarz w kaplicy Zygmuntowskiej zalicza się do realizacji najbardziej prestiżowych. Modele dla swoich dzieł - spośród których medale stanowią zaledwie niewielki

48 Zob. J. Chipps Smith, dz. cyt., s. 329-330; M. Teget-Welz, Biographien der Medailleure, w: Wettstreit
in Erz.., dz. cyt., s. 335; H. Maué, Augsburg und Nürnberg, w: tamże, s. 324-325.

49 M. Gumowski, Medale Jagiellonów..., dz. cyt., s. 62 , nr kat. 63; G. Habich, Die deutschen Schaumünzen..., dz. cyt., Bd. 2, nr kat. 986. Por. Polen. Goldmedail

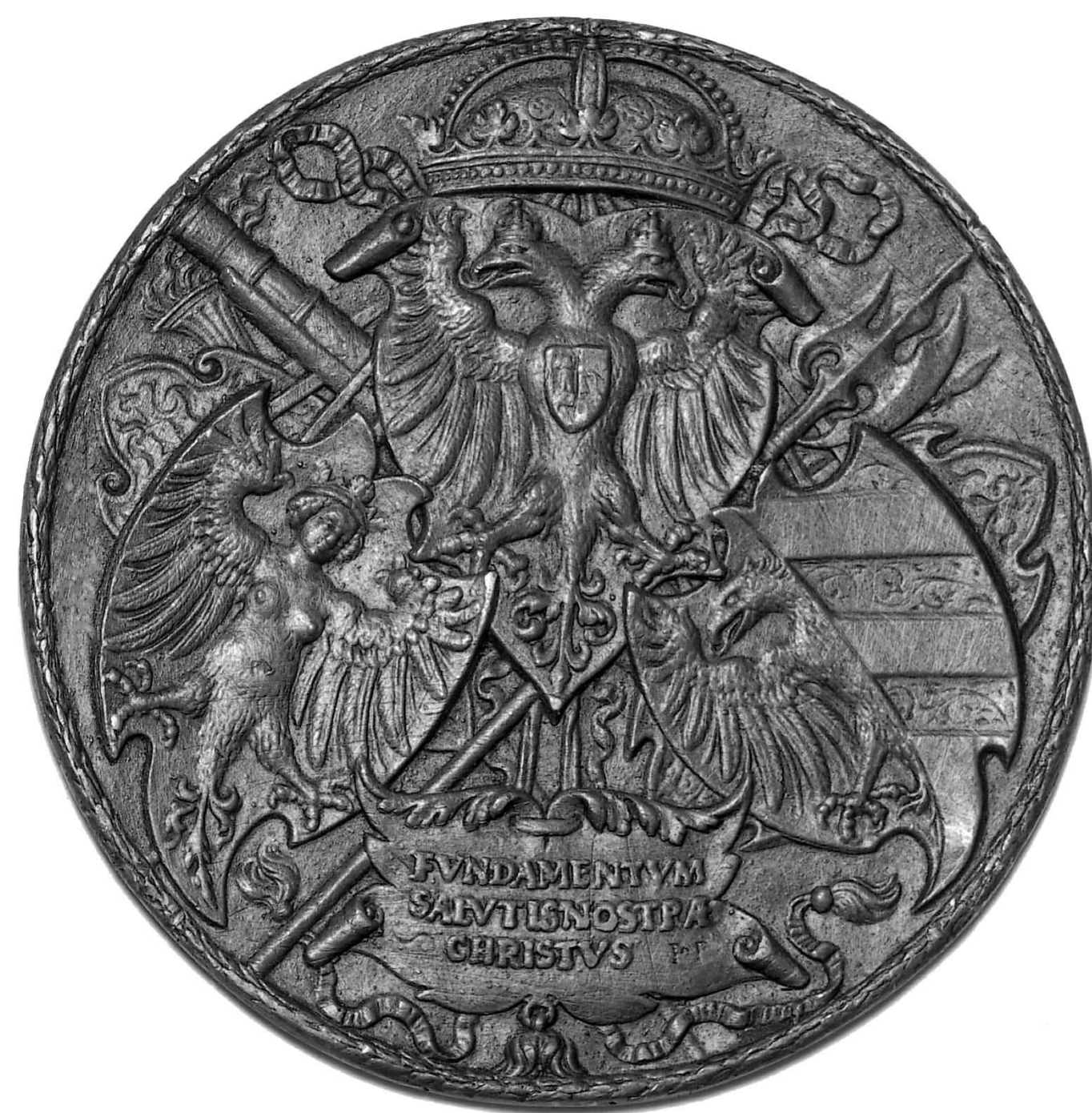

20. Peter Flötner i in., Medal upamiętniający budowę bastei przy zamku w Norymberdze, 1538 r., Londyn, Victoria \& Albert Museum. Fot. Victoria \& Albert Museum

procent - wykonywał częstokroć, podobnie jak Gebel, w wapieniu z Solnhofen ${ }^{50}$. Oprócz wzmiankowanego ołtarza istnieją przynajmniej dwa inne dzieła fundowane przez Zygmunta Starego, które w mniej lub bardziej ścisły sposób można łączyć z twórczoscią tego wybitnego artysty. Są to mianowicie złoty relikwiarz na kość palca św. Zygmunta, wykonany do mauzoleum królewskiego w 1533 r. przez Melchiora Baiera najprawdopodobniej według modelu 50 M. Teget-Welz, Biographien der Medailleure..., dz. cyt.,
s. 323-324.
Flötnera, i para świeczników, sporządzona trzy lata później przez tych samych artystów, również do kaplicy Zygmuntowskiej ${ }^{51}$ Ponieważ data widniejąca w otoku rewersu omawianego medalu jest zbieżna $\mathrm{z}$ rokiem ukończenia ołtarza srebrnego, poświadczonym napisem i datą na predelli, uzasadnione jest przypuszczenie, że został on zamówiony przez króla lub kogoś z jego najbliższego otoczenia u wypróbowanych

51 D. Nowacki, Norymberskie złotnictwo w kręgu dworu ostatnich Jagiellonów, „, Chronicon Palatii Magnorum am 3. September 1538, w: Wettstreit in Erz..., dz. cyt. 
norymberskich rzemieślników. Tym samym wpisuje się on w swoistą prawidłowość, charakteryzującą patronat styczny Zygmunta I, która nosi - jak ostatnio zauważył Marek Walczak - cechy ostatnio zauwazyt Marek Walczak - cechy stylowego duallzmu. Winicjatywach krolewskich, podejmowanych w zakresie rzeźby drewnianej i odlewów z brązu, malarstw czy rzemiosła artystycznego, zauważaln jest mianowicie przywiązanie do tradycji północnej, w szczególności do dzieł zamawianych w Norymberdze, natomiast predylekcja do form włoskich wyróżnia jedynie dzieła architektury i rzézby kamienne

Powyższe medale z pewnością odgrywały role w działalności politycznej Zygmunta I i Bony Sforzy. Informacje źródłowe dotyczące najwcześniejszych medali wykonanych w oparciu o modele Hansa schencka, ujawniają wprawdzie inicjatywy nie tyle króla, ile jego bliskich doradców Krzysztofa Szydłowieckiego i Seweryna Bonera, ale treści ideowe zawarte w inskrypcjach tych medali (zwłaszcza winskipo w Warszawie iw Kunsthistorisch wusszaw wiedniu) oraz formuta Museum w Wiedniu) oraz formuła widniejącego na nich portretu, która odpowiada oficjalnej ikonografii Zygmunt znanej z innych przedstawień króla, takich na przykład jak graficzny portret załączony do Statutów sejmowych Zygmunta I opublikowanych w roku 1524, nie pozostawiają wattpliwości, że powstały one, jeśli nie z woli Zygmunta Stareg

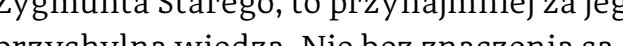
przychyną wiedzą. Nie bez znaczenia są Schencka a więc okres bezposredio po Schencka, a więc okres bezpośrednio po hołdzie pruskim, dzięki któremu Królestw Polskiemu podporządkowana została zachodnia część zlikwidowanego państwa

52 M. Walczak, Kraków i Norymberga - zwiqzki renesansu, w: Mistrz i Katarzyna. Hans von Kulmbac i jego dzieła dla dla Krakowa [katalog wystawy], red. zakonnego (od tego momentu zwana Prusami Królewskimi) i zhołdowana jego cześć wschodnia (od tego momentu zwana Prusami Ksiązęcymi) Przewijajace się cresce wnapisach tych medall tematy triumfu imęstwa oraz odniesienia do zasięgu geograficznego władzy króla Polski należy traktować jako komentarz do aktualnej sytuacji politycznej, w szczególności zaś do stabilizacji stosunków na północy, którą Zygmunt I mógł sobie poczytywać za sukces. Medale odlane w roku 1532 koncentrowały się na innym aspekcie polityki królewskiej, prezentowały bowiem nie tylko króla, lecz także członków jego rodziny: Bonę i dwoje najstarszego potomstwa Zygmunta Augusta i Izabelę Jagiellonkę. Pozwalają się one interpretować jako spójny ideowo zespół, prezentujący szczęśliwe małżenstwo, którego owocem są monarsze dzieci. Podkreślały tym samym wątek dynastyczny, co postrzegać należy w kontekście sytuacji politycznej, jaka nastąpiła Europie po klęsce Wegier w bitwie pod Wohoczem w $1526 \mathrm{r}$ i przedwczesnej śmierw ciLudwika Jagillonczyka. W tym waśnie okresie skonsolidowalo się na dworze królewskim stronnictwo antyhabsburskie zawiązane wokół Bony, dążące początkowo do zajęcia przez Jagiellonów wakujących tronów czeskiego i węgierskiego, a później do stworzenia silnej przeciwwagi dla ekspansywnej polityki Habsburgów. Okres, w którym powstały omawiane medale, stanowił moment szczytowy wpływów Bony na sprawy pá́stwor spawy panstwowe, wh korym starała się dynas tę trwalego pokoju Polski z Turcja dynastię trwałego pokoju Polski z Turcją (rzecz sfinalizowana w styczniu 1533 r.) i zapewne dojrzewała do wydania swej najstarszej córki (tj. Izabeli) za Jana Zapolyę, nowego króla Węgier (do czego doszło ostatecznie w roku 1538)53. Wydaje się zatem 3 Zob. M. Bogucka, Bona Sforza, Wrocław 2009, prawdopodobne, że medale, tak wyraźnie akcentujące wielkość dynastii jagiellońskiej zasilonej krwią Sforzowny, powstały pod przemożnym wpływem tej ostatniej, zapewne w związku z jej szeroko zakrojon działalnością dyplomatyczną, zmierzającą do umocnienia pozycji Jagiellonów na arenie międzynarodowej Ostatni z medali Zygmunta I, odlany w 1538 r., zosta zapewne wykonany z okazji zaręczyn Elżbiety Habsburżanki i Zygmunta Augusta,

\section{STRESZCZENIE}

\section{KILKA UWAG O MEDALACH}

PORTRETOWYCH ZYGMUNTA I STAREGO

Na początku XVI w. medal portretowy był jedną z najoryginalniejszych form reprezentacji, która dzięki dużej ilości informacji na w niewielkim, trwałym, mobilnym i ławiew odpowiadała renesansowemu postulatowi sławy i nieśmiertelności. Możliwości, jakie oferował ten gatunek artystyczny, zostały zauważone w dworskim kregu Zygmunta I Starego, co zaowocowało kilkoma seriam lanych i bitych w różnych metalach medali przedstawiających polskiego króla, powstałych na przestrzeni drugiego i trzeciego dziesięciolecia XVI w. W artykule poddacio row poddanoprowe jaką mogły one pełnić w praktyce władzy jaką mogły
Zygmunta I.

\section{SŁOWA KLUCZOWE}

medal, Jagiellonowie, portret, renesans które spisano 16 czerwca tego roku. Według Mariana Gumowskiego medal był rozdawazemplarze lane w złocie pochodzily z posagu Elìbiety - 30000 dukatów przesłanych do Polski ${ }^{54}$.

54 M. Gumowski, Medale Jagiellonów..., dz. cyt., s. 77,

nr kat. 7j. . Wojciechowski, Caraglio w Polsce..,

dz. cyt., s. 42 ; tenże, Caraglio..., dz. cyt., s. 354 ,
M. Morka, Sztuka dworu.., dz. cyt., s. 326.

\section{SUMMARY}

SOMENOTES ON THE PORTRAIT MEDALS OF SIGISMUND I THE OLD

At the dawn of the sixteenth century portrait medals counted among the most orginal forms of representation which providing plenty of information on represented individual and accumulating itin a small, durable, dual and accum lating in a small, durable, moble and easily reproducible object, met the Renaissance demand of fame and immortality Advantages of this medium have been noticed in the courtly circle of king of Poland

Sigismund I the Old (1507-1548) thus leading to creation of several series of medals cast and strack in various metals in the second and third decade of the sixteenth century. The paper discusses authorship of these medals, as well as circumstances of their production and the role they could have played in the propa-
ganda of Sigismund I's power.

\section{KEYWORDS}

medal, Jagiellonians, portrait, Renaissance 


\section{BIBLIOGRAFIA}

Bogucka M., Bona Sforza, Wrocław 2009. Cante A., Der Bildhauer und Medailleur Han Schenck, oder Scheußlich. Ein Künstler der Renaissance in Zeiten der Reformation, Bd. 1, Berlin 2007.

Chipps Smith J., German Sculpture of the Later Renaissance, c. 1520-1580. Art in an Age of Uncertainty, Princeton-New Jersey 1994.

Cupperi W., Grenzverkehr, w: Wettstreit in Erz. Porträtmedaillen der deutschen Renaissance, hrsg. von W. Cupperi, M.Hirsch, A. Kranz, U. Pfisterer, Berlin-München 2013, s. 270-280.

The Currency of Fame. Portrait Medals of the Renaissance, ed. S.K. Scher, New York 1994

Eckhardtówna J., Potrzeby nauki polskiej w zakresie badań nad włoskimi źródłami polskiej plastyki renesansowej, „Sprawozdania Poznańskiego Towarzystwa Przyjaciół Nauk", r. 12, 1938 (1939), s. 41-46.

Grabski I. Le immagini del re di Polonia Sigismondo I e della Famiglia reale sulla serie di medaglie del 1532 di G. M. Mosca detto il Padovano nella collezione già estense a Modena, w: Italia, Venezia e Polonia tra Medio Evo e età moderna ed. V. Branca, S. Graciotti, Firenze 1980, s. 571-584.

Graham Pollard J.,Renaissance Medals. The Collection of the National Gallery of Art, Systematic Catalogue, vol. 2, Washington 2007

Cumowski M. Medale Jagiellonów, Kraków 1906

Gumowski M., Hans Schwarz i jego polski medale, „Prace Komisji Histori Sztuki", 1917, t. 1, nr 1, s. 88-108.

Gumowski M., Jan Dantyszek i jego medale, „Zapiski Towarzystwa Naukowego w Toruniu", t. 8, 1929, nr 1, s. 3-19.
Habich G., Die deutschen Schaumünzen des XVI. Jahrhunderts, Bd. 1, München 1929; Bd. 2, München 1932.

Habich G. Studien zur deutschen

Renaissancemedaille. IV. Christoph

Weiditz, „Jahrbuch der Königlich

Preussischen Kunstsammlungen", Bd. 34, 1913, nr 34, s. 1-35.

Kieszkowski J., Kanclerz Krzysztof Szydłowiecki. Z dziejów kultury i sztuki zygmuntowskich czasów, t. 2, Poznań 1912.

Kopera F., Dary z Polski dla Erazma

$z$ Rotterdamu w Historycznem Muzeum Bazylejskiem, „Sprawozdania Komisyi do Badania Historyi Sztuki w Polsce", t. 6, 1900, s. 110-138.

Kranz A., Riether A., Kopf oder Zahl. Vervielfachte Vielfalt des Porträts in Medaille und Druckgraphik, w: Dürer Cranach - Holbein. Die Entdeckung des Menschen: Das deutsche Porträt um 1500 [katalog wystawy], hrsg. von S. Haag, C. Lange, C. Metzger K. Schütz, München 2011, s. 213-219.

Markham Schulz A., Giammaria Mosca, called Padovano: a Renaissance sculptor in Italy and Poland, University Park 1998.

Medale polskie i z Polska zwiazane z okresu Pierwszej Rzeczypospolitej. Katalog zbiorów. Zamek Królewski w Warszawie - Muzeum. Fundacja Zbiorów im. Ciechanowieckich, oprac. J. Zacher, G. Śnieżko, M. Zawadzki, współpraca M. Męclewska, t. 1, Warszawa 2019.

Morka M. Sztuka dworu Zygmunta I Starego. Treści polityczne i propagandowe, Warszawa 2006.

Morka M., The Beginning of Medallic Art in Poland during the Times of Zygmunt and Bona Sforza, ,Artibus et Historiae", vol. 29, 2008, nr 58, s. $65-87$.

Matzke M.,Polen. Goldmedaille nach Art des Hans Schwarz auf den polnischen König Sigismund I, w: Die grosse
Kunstkammer: Bürgerliche Sammler und Sammlungen in Basel, hrsg. von S. Söll-Tauchert, Basel 2011, S. 172-174.

Nowacki D. Norymbershie zlotnictwo whegu dworu ostatnich Jagiellonów, "Chronicon Palatii Magnorum Ducum Lithuaniae", vol. 3, 2015 S. $210-225$

Pfisterer U., Wettstreit der Köpfe und Künste. Repräsentation, Reproduktion und das neue Bildmedium der Medaille nördlich der Alpen, w: Wettstreit in Erz. Renaissance, hrsg. von W. Cupperi, M. Hirsch, A. Kranz, U. Pfisterer, Berlin-München 2013, s. 15-28.

Piech Z., Monety, pieczęcie i herby w systemi symboli władzy Jagiellonów, Warszaw 2003

Pociecha W., Królowa Bona (1494-1557). Czasy i ludzie Odrodzenia, t. 2, Poznań 1948

Ties H.-P., Hans Schenck oder Scheußlich König Sigismund I von Polen 1527, w: Wettstreit in Erz. Porträtmedaillen der deutschen Renaissance, hrsg. von W. Cupperi, M. Hirsch, A. Kranz, U. Pfisterer, Berlin-München 2013 s. 274.

Trusted M., German Renaissance Medals: A Catalogue of the Collection in the Victoria \& Albert Museum, Gloucester 1990.

Seeger J.F., Hans Schenck (genannt Scheußlich), Ein deutscher Bildhauer des 16. Jahrhunderts, Berlin 1932.
Stahr M., Zygmunt August, 1532, w: Medale polskie i z Polską zwiazane od XVI do XVIII wieku. Katalog zbiorów Muzeum Narodowego w Poznaniu, t. 11, oprac. taż, Poznań 2008, s. 26-27.

Szwagrzyk J.A., Moneta, medal, order. Katalog wystawy własnych zbiorów numizmatycznych Biblioteki Zakładu Narodowego im. Ossolińskich - PAN, Wrocław-Warszawa-KrakówGdańsk 1971.

Walczak M., Kraków i Norymberga - związki $w$ dziedzinie sztuki na przełomie średniowiecza i renesansu, w: Mistrz i Katarzyna Hans von Kulmbach i jego Kata da. Krakowa, zzieła dla Krakowa, red. M.P. Kruk, A. Hola, M. Walczak, S. 107-135.

Wettstreit in Erz. Porträtmedaillen der deut schen Renaissance, hrsg. von W. Cupperi, M. Hirsch, A. Kranz, U. Pfisterer, Berlin-München 2013.

Więcek A., Dzieje sztuki medalierskiej w Polsce, Kraków 1972.

Winter H., Medaillen auf Herrscher des ungarischen Mittelalters. Ein Beitrag zur Entwicklung der Porträtmedaille im Königreich Ungarn, w: M. Gyöngyössy, H. Winter, Münzen und Medaillen des ungarischen Mittelalters 1000-1526, hrsg. von M. Alram, H. Winter, Wien 2007, s. 37-47.

Wojciechowski J., Caraglio w Polsce,

„Rocznik Historii Sztuki”, r. 42, 200o, S. 5-63.

Wojciechowski J Caraglio, Warszawa $201 \%$ 